\title{
Duality of trophic supply and hydrodynamic connectivity drives spatial patterns of Pacific oyster recruitment
}

\author{
Lagarde Franck 1, 2, *, Fiandrino Annie 1, Ubertini Martin ${ }^{3}$, Roque D'Orbcastel Emmanuelle 1, \\ Mortreux Serge ${ }^{1}$, Chiantella Claude ${ }^{1}$, Bec Beatrice ${ }^{4}$, Bonnet Delphine ${ }^{4}$, Roques Cécile ${ }^{4}$, \\ Bernard Ismael ${ }^{5}$, Richard Marion ${ }^{1}$, Guyondet Thomas ${ }^{6}$, Pouvreau Stephane ${ }^{7}$, Lett Christophe 8
}

${ }^{1}$ MARBEC, Univ. Montpellier, CNRS, IRD, Ifremer, 34200 Sète, France

2 Sorbonne Université, Collège Doctoral, 75005 Paris, France

3 POS3IDON S.A.S, 35400 Saint-Malo, France

${ }^{4}$ MARBEC, Univ. Montpellier, CNRS, IRD, Ifremer, 34095 Montpellier, France

${ }^{5}$ Eurêka Mer S.A.S, 22740 Lézardrieux, France

${ }^{6}$ Ministère Pêche et Océans, Moncton, NB E1C 5K4, Canada

7 LEMAR, Ifremer, CNRS, IRD, UBO, 29280 Plouzané, France

8 MARBEC, Univ. Montpellier, CNRS, IRD, Ifremer, 34200 Sète, France

* Corresponding author : Franck Lagarde, email address : franck.lagarde@ifremer.fr

\begin{abstract}
:
The recent discovery of Pacific oyster Crassostrea gigas (also known as Magallana gigas) spatfields in a Mediterranean lagoon intensely exploited for shellfish farming (Thau lagoon) revealed significant contrasts in spatial patterns of recruitment. We evaluated the processes that drive spatial patterns in oyster recruitment by comparing observed recruitment, simulated hydrodynamic connectivity and ecological variables. We hypothesized that spatial variability of recruitment depends on (1) hydrodynamic connectivity and (2) the ecology of the larval supply, settlement, metamorphosis, survival and biotic environmental parameters. We assessed recruitment at 6-8 experimental sites by larval sampling and spat collection inside and outside oyster farming areas and on an east-west gradient, from 2012-2014. Hydrodynamic connectivity was simulated using a numerical 3D transport model assessed with a Eulerian indicator. The supply of large umbo larvae did not differ significantly inside and outside oyster farming areas, whereas the supply of pediveligers to sites outside shellfish farms was structured by hydrodynamic connectivity. Inside shellfish farming zones, unfavorable conditions due to trophic competition with filterfeeders jeopardized their settlement. In this case, our results suggest loss of settlement competence by oyster larvae. This confirms our hypothesis of top-down trophic control by the oysters inside farming zones of Thau lagoon in summer that fails to meet the ecological requirements of these areas as oyster nurseries. Knowledge of oyster dispersal, connectivity and recruitment in coastal lagoons will help local development of sustainable natural spat collection. On a global scale, our method could be transposed to other basins or used for other species such as mussels, clams or scallops, to better understand the spatial patterns of bivalve recruitment. Management of the oyster industry based on natural spat collection will help develop a sustainable activity, based on locally adapted oyster strains but also by reducing the risks of transferring pathogens between basins and the global carbon footprint of this industry.
\end{abstract}


Keywords: Crassostrea gigas, Coastal lagoon, Larval ecology, Spatial patterns, Connectivity, Settlement, Recruitment, Oligotrophication 


\section{INTRODUCTION}

More knowledge on reproduction and recruitment is needed to improve our understanding of marine population dynamics and for fishery stock management, both of which face changing conditions ranging from local anthropogenic pressures to global climate change (Hunt \& Scheibling 1997a, Cowen et al. 2007, Pérez-Ruzafa et al. 2018). The early life of most marine benthic invertebrates includes spawning, larval development, dispersal (Todd 1998, Cowen \& Sponaugle 2009), settlement (Gaines et al. 1985), and ultimately recruitment of juveniles into the host ecosystem (Keough \& Downes 1982). These different processes are incorporated in the concept of marine population connectivity between spawning and recruitment areas (Pineda et al. 2007). Marine connectivity is defined by the rate of transfer of organisms between locations (Bryan-Brown et al. 2017). Numerical models are widely used to assess hydrodynamic connectivity in order to compare different release zones (Solidoro et al. 2004, Fiandrino et al. 2017), identify dispersal pathways, and quantify cumulated fluxes of tracers per volume or area (Ghezzo et al. 2015, Lagarde et al. 2015, Thomas et al. 2016). These models are also used to highlight physical versus biological and ecological functioning at different spatial and temporal scales. The number of studies conducted to improve our knowledge of connectivity has increased markedly over the last 30 years (Elsäßer et al. 2013, Bryan-Brown et al. 2017). Recently, connectivity studies that combine simulation modeling and field work with direct observations of larval development have been conducted (Smyth et al. 2016). However, Ghezzo et al. (2015) drew attention to the lack of connectivity studies combining modeling and field work that include direct data on larval development and environmental factors. The aim of the present study was to fill this knowledge gap by studying the transition from pelagic to benthic life of the Pacific oyster (Crassostrea gigas also known as Magallana gigas) in a coastal, nanotidal, and semi-enclosed Mediterranean lagoon. 
In most marine larvae, the transition between pelagic and benthic development is induced by settlement and metamorphosis competences that insure successful recruitment (Coon et al. 1990). Settlement is initially driven by the hydrodynamics of the ecosystem (Todd 1998, Wing et al. 2003), but the biological properties of the organisms also play an important role in the physiological (trophic diet, food limitation or energy depletion), ethological (migration, trophic settlement trigger) and ecological (predation, competition) aspects of the development phase (Hunt \& Scheibling 1997a).

Despite the economic importance of Pacific oysters C. gigas, there are still gaps in our knowledge of their in situ life, including early benthic settlement and post settlement stages (Bayne 2017, Lagarde et al. 2018). The origins of recruitment variability are still not completely known because of species and habitat specificities and the complexity of ecosystem dynamics that prevent generalization (Roughgarden et al. 1988). Such complexity is best explained by studying the general functioning of recruitment and production of each species at local scale (Hori et al. 2017).

In a recent study, we reported that the discovery of Pacific oyster spatfields in the Mediterranean Thau lagoon highlighted the influence of strong temporal biological and ecological processes on recruitment (Lagarde et al. 2017). These results suggest that in the Mediterranean Thau lagoon, time windows for oyster recruitment depend on autotroph vs. heterotroph species domination related to water temperature and oxygen conditions. Such results are best obtained by examining several larval stages, to determine the relative importance of each stage and any potential ecological problems in larval development (Hunt \& Scheibling 1997b, Ghezzo et al. 2015, Pouvreau 2018). In addition to the temporal component, spatial patterns in settlement or early post-settlement are known to influence the distribution and abundance of benthic marine invertebrate juveniles and adults (Hunt \& Scheibling 1997a, Thomas et al. 2016). 
In the present study, the spatial variability of oyster recruitment was investigated using the connectivity approach, and more broadly considering further oyster trophic limitations (i.e. nanophytoplankton and microphytoplankton) due to oligotrophication of Thau lagoon (Collos et al. 2009). Oligotrophication results from a decrease in nutrient inputs due to the society's demand for environmental recovery (Collos et al. 2009, Hori et al. 2017). Our specific aim was to explain the spatial pattern of recruitment of $C$. gigas with data produced by both field observations and hydrodynamic modeling in order to establish_relationships between larval supply, connectivity and ecological functioning. To this end, we tested the hypothesis that the spatial variability of recruitment depends on hydrodynamic connectivity and on larval ecology at settlement and recruitment on immersed collectors(Collos et al. 2009, Souchu et al. 2010, Lagarde et al. 2017). Our overall objective was to disentangle and evaluate the comparative roles of connectivity and biotic factors. Understanding the population connectivity of oysters should result in societal gain by informing the development of a sustainable natural spatfall collection practices. On a more global scale, the added value of this work will be improving the management of areas intensely exploited by mollusk farming where oligotrophication and sustainable exploitation have to be adjusted to insure continuing ecological functions (such as a mollusk nursery) and the ecosystem services they provide such as oyster spat collection.

\section{Materials and Methods}

\subsection{Study site}

The study site is the French Thau Lagoon located on the northern coast of the Mediterranean Sea on the Gulf of Lion (Figure 1). This restricted nanotidal semi-enclosed hydrosystem (Kjerfve 1994) covers an area of 7,500 ha $(19 \times 4.5 \mathrm{~km})$ on a northeast-southwest axis and has a mean depth of four meters (Fiandrino et al. 2017). The lagoon is influenced by seawater inputs 
from the Mediterranean Sea that enter through two artificial inlets, the Sète channel in the north, which accounts for $90 \%$ of seawater exchanges and the Pisse-Saumes channel in the south. Wild oyster stocks are negligible compared to oyster farming. Twenty percent of the total Thau Lagoon area is dedicated to intense cultivation of mussels and oysters; other areas are devoid of shellfish farming and are used for fishing.

\subsection{Larval and recruitment abundance}

Eight spatfall sites in Thau lagoon (Figure 1) were monitored to assess pre-settled oyster larvae and post-settled spat abundances in pelagic and benthic compartments: three sites are located inside the shellfish farming zones (hereafter ISFZ) (Marseillan_ISFZ, Meze_ISFZ and Bouzigues_ISFZ) and five outside (hereafter OSFZ) (Marseillan_OSFZ, Listel_OSFZ, Meze_OSFZ, Bouzigues_OSFZ and Balaruc_OSFZ).

Pelagic and benthic larval abundances of $C$. gigas were assessed in the years 2012, 2013 and 2014 from June to September, which corresponds to the reproductive window of Pacific oyster in Thau Lagoon (Figure 2). Pelagic larvae were quantified twice a week using a standard protocol provided by the French Oyster Larvae Monitoring Network (French acronym VELYGER) (Pouvreau et al. 2013, Pouvreau 2016). A sampling volume of $1.5 \mathrm{~m}^{3}$ was pumped and filtered through $40 \mu \mathrm{m}$ plankton net to count oyster larvae ranging on average from Dshaped larvae (size between 60 and $105 \mu \mathrm{m}$ ), small and medium umbo larvae (106 to $235 \mu \mathrm{m}$ ) to large umbo larvae (235 to $400 \mu \mathrm{m}$ ) (Pouvreau et al. 2016). Benthic oyster abundances were estimated on plate collectors (coupelles) every two weeks at three different settler stages: presettled larvae as pediveligers, whose size range from 190 to $300 \mu \mathrm{m}$, young post-larvae after metamorphosis ranging in size from 300 to $1000 \mu \mathrm{m}$ (Coon et al. 1990, Pechenik 2006) and newly settled spat ranging from 1 to $8 \mathrm{~mm}$ (Arakawa 1990). 
In the present study, larval development was studied based on four different development stages (D-larvae, large umbo larvae, pediveliger and oyster spat). Settlement is defined here as a process of becoming familiar with the substrate with the onset of a behavioral search for a suitable location and ending with cementation (Pawlik 1992, Rodriguez et al. 1993, Pineda et al. 2009). Metamorphosis is the next stage before recruitment (Coon et al. 1990, Fitt et al. 1990). Recruitment is confirmed when oyster juveniles reach 1 to $8 \mathrm{~mm}$ in size (Lagarde et al. 2017) and can be seen with the naked eye by observers after the collectors have been immersed for four weeks. (Booth \& Brosnan 1995).

To enable collection of these benthic stages, the sites were equipped with two series of three replicate collectors (Figure 3, Figure 4 and Figure 5). One set was submersed for two weeks to collect pediveligers and the second set was submersed for four weeks to collect oyster spat (Figure 2). Each collector was replaced after four weeks of submersion; meaning that at each sampling site, one series of collectors was replaced every two weeks throughout the summer.

\subsection{Environmental measurements}

Environmental parameters (hydrological and plankton samples) were recorded at weekly intervals from June to September in 2012, 2013 and 2014 close to spatfall sites Listel_OSFZ, Bouzigues_ISFZ and Marseillan_ISFZ. Temperature and salinity were measured twice a week using with WTW® probes positioned between 1 and $1.5 \mathrm{~m}$ below the surface, and averaged weekly.

The biomass and abundance (Table 1$)$ of the planktonic community: bacteria $(<1 \mu \mathrm{m})$, pico- $(<$ $3 \mu \mathrm{m})$, nano- $(3 \mu \mathrm{m}$ to $20 \mu \mathrm{m})$ and microphytoplankton $(>20 \mu \mathrm{m})$, protozooplankton and mesozooplankton, were monitored as biomass and abundance at weekly intervals from June to September in 2012, 2013 and 2014 close to spatfall sites Listel_OSFZ, Bouzigues_ISFZ and Marseillan_ISFZ (but not at Listel_OSFZ in 2012) (Lagarde et al. 2017, REPHY - French Observation and Monitoring program for Phytoplankton and Hydrology 2017). Abundances of 
potential predators and trophic competitors of $C$. gigas larvae were estimated by taxonomic identification using a binocular microscope (Rose 1933). The 'trophic competitors' group was determined as the sum of copepod nauplii, annelids, barnacles, ascidia and gastropod larvae. 'Potential predators' were assessed as the sum of cladocerans (Penilia avirostris, Podon spp., and Evadne spp.), decapod larvae, mysids and hydrozoa (Obelia spp.).

\subsection{Hydrodynamic connectivity index}

We used an Eulerian approach to study the hydrodynamic processes (Pineda \& Reyns 2018). We define hydrodynamic connectivity (Ghezzo et al. 2015) between a finite emission volume of a shellfish zone $\left(\mathrm{V}_{\mathrm{E}}\right)$ and a finite destination volume $\left(\mathrm{V}_{\mathrm{D}}\right)$ as the amount of a passive dissolved conservative tracer released from $\mathrm{V}_{\mathrm{E}}$ and entering $\mathrm{V}_{\mathrm{D}}$ over a given period of time $(\Delta \mathrm{T})$. The intrinsic movement of larvae (horizontal swimming and vertical migration) and their mortality were not considered because the focus of the present study was only on the hydrodynamic aspect of connectivity.

To assess hydrodynamic connectivity, we used the 3-dimensional hydrodynamic Model for Application at Regional Scale (MARS-3D). The MARS-3D model (Lazure \& Dumas 2008) has already been used to simulate water exchange between the Thau lagoon and the Mediterranean sea and validated (Fiandrino et al. 2017). The model grid has a spatial resolution of $100 \mathrm{~m}$. Bathymetry was taken from the 2010 survey by the "Cellule de qualité des Eaux Littorales" of Occitanie/Languedoc-Roussillon Region (Bernard et al. 2013). Ten sigma layers are distributed on the vertical axis to represent the bottom and the surface boundary layers. A passive dissolved conservative tracer was homogeneously released throughout the water column in shellfish farming areas at the beginning of the simulation and used to materialize the circulation of water bodies associated with larval transport. The amount of tracer $\mathrm{Q}_{\mathrm{D}}\left(i, j, T_{\text {Integ }}\right)$ entering the volume of each cell of the horizontal 2D-grid (integrated over the whole water 
column) was cumulated over $T_{\text {Integ }}=18$ days, corresponding to the potential period of larval settlement (Lagarde et al. 2015, Pouvreau 2015). Integration started four days after the tracer was released to reflect the minimum pelagic larval duration $\left(T_{P L D}\right)$ observed for $C$. gigas.

The local hydrodynamic connectivity index $\mathrm{CI}\left(i, j, T_{\text {Integ }}\right)$ was then defined as the ratio of $\mathrm{Q}_{\mathrm{D}}(i$, $j, T_{\text {Integ }}$ ) to the total amount of tracer released in shellfish farmed areas $Q_{E}=\left[C_{P C T}\right] . V_{E}$ where $V_{E}$ is the combined volume of all shellfish farming areas and $\left[\mathrm{C}_{\mathrm{PCT}}\right]$ is the vertical concentration in all cells of the grid corresponding to shellfish farming areas $(n=566)$. To compare observed recruitment and simulated hydrodynamic connectivity, $C I$ values were calculated for the date each collector was harvested to estimate the abundance of pediveligers, i.e. every two weeks from June $1^{\text {st }}$ to October $1^{\text {st }}$ in 2012, 2013 and 2014.

$$
C I\left(i, j, T_{\text {Integ }}\right)=\frac{\frac{Q_{D}\left(i, j, T_{\text {Integ }}\right)}{Q E} / T_{\text {Integ }}}{}
$$

\subsection{Simulation setup, forcing and open boundary conditions of the MARS-3D model}

Several simulations were run to scan the variability of starting conditions and the following chronology between June $1^{\text {st }}$ and September $29^{\text {th }}$ with 3 -day resolution. Hence, the difference between the start of two sequential simulations was three days. Fifty simulations were started throughout this period, and each simulation ended one month later. In each simulation, the passive conservative tracer was released at the beginning of the simulation with a uniform horizontal concentration in each grid cell containing shellfish farms. A preliminary simulation was run to calculate and record the daily hydrodynamic states of the system from April $1^{\text {st }}$ until October $1^{\text {st }}$ in each of the three study years. The recorded daily state of the system was used as the initial hydrodynamic conditions for each of the 50 simulations. 
This simulation setup assumed that tracer releases were synchronous. The synchronicity hypothesis is based on our previous observations that efficient spawning events are synchronous (Lagarde et al. 2015). Since the concentration is a constant $\left(\mathrm{C}_{\mathrm{PCT}}\right)$, the total quantities of tracer released per zone only depend on the volume of the zones (Volume Marseillan/Volume meze/ Volume Bouzigues $=1 / 1.5 / 4)$. Thus, the ratio between $\mathrm{QE}$ Marseillan, QE Meze, QE Bouzigues is equal to the ratio of the volumes of the zones.

A detailed description of atmospheric forcing and open boundary conditions for the Thau lagoon is provided in Fiandrino et al. (2017). Meteorological data were used to describe the state of the atmospheric boundary layer: wind speed at a height of $10 \mathrm{~m}$, and air pressure at sea level. Chronologies of wind speed and direction were measured directly above Thau lagoon at Marseillan_ISFZ station with a Campbell Scientific datalogger (CR1000) and Ultra Sonic Wind Sensor (Windsonic Inc.). Wind speed and direction were considered to be spatially homogenous across the lagoon (Fiandrino et al. 2017). These data were acquired at one minute intervals and were averaged over 10 minutes to be consistent with open boundary conditions.

At the open boundary, the model was forced by tide gauge data recorded at 10 minute intervals in Sète channel (Holgate et al. 2013) with 2016 database from the Permanent Service for Mean Sea Level (PSMSL). Temperatures and salinity at the open boundary were monitored every two weeks by the French National Phytoplankton and Phycotoxin Monitoring Network (REPHY, 2017) at the Sète-Mer station, located just off the Sète channel inlet.

\subsection{Data analysis}

Statistical analyses were performed with $\mathrm{R}$ statistical software (R Core Team 2015), version 3.5.0 (2018-04-23). The experimental approach was based on correlative and statistical modeling approaches. 
An ANOVA was performed to test the effect of year and sampling site on the recruitment of observed spat abundances with Power Box-Cox transformation (lambda $=-0.63$ ). Normality and heteroscedasticity of residuals were checked by visual inspection. Oyster spat recruitment was displayed graphically using comparison of means with $95 \%$ confidence intervals.

Box and whisker plots were used to distinguish the effect of ISFZ from the effect of OSFZ on larval abundance at the four different stages of development (D-larvae, large umbo larvae, pediveligers and spat). We tested the hypothesis that larval abundances did not vary according to ISFZ-OSFZ biocoenosis (under $\log _{10}$ transformation) with a parametric analysis of variance if prerequisites of normality, homoscedasticity and independence were respected; otherwise, we used a non-parametric Kruskall-Wallis test.

The 50 simulations over the period from June $1^{\text {st }}$ to September $29^{\text {th }}$ were analyzed to establish yearly maps of averaged hydrodynamic connectivity in the three study years. The mean hydrodynamic connectivity index was averaged from the 50 values of indicators calculated over periods of 18 days corresponding to the maximum duration of larval settlement.

A simulated connectivity indicator was calculated using the dates on which spat was collected at the eight experimental sampling sites. The connectivity indicators are presented in box and whiskers plots. An analysis of variance model was fitted with additional Tukey contrasts multiple comparisons of means ('multcomp' package) to differentiate the connectivity levels at the different sampling sites.

The relationship between simulated connectivity and the abundances of the different larval stages is illustrated by means and standard error bars on scatterplots in both the $\mathrm{x}$ and $\mathrm{y}$ directions associated with linear regression lines. ANCOVA was used to compare the ISFZ / OSFZ regression model with respect to the application conditions (independence, linearity and homoscedasticity). 
To further investigate the link between larval abundance and the plankton environment, we used a linear multiple regression with transformed data. The adjusted R-squared was maximized without minimizing collinearity.

\section{RESULTS}

The aim of this study was to explain the spatial pattern of Pacific oyster recruitment by comparing observed recruitment, simulated hydrodynamic connectivity and spatial patterns of environmental drivers.

\subsection{Spatial variability of oyster spat recruitment and larvae abundances}

We found significant differences in oyster spat recruitment ( $\mathrm{p}<0.05$, situation:year), in accordance with the interaction between year and situation (inside or outside the shellfish farmed zone) in Thau lagoon (Figure 6, Table 2). In 2012, the first significant spat collection was recorded on 13 August with 126 and 47 spat ind. plate ${ }^{-1}$ at Listel_OSFZ and Bouzigues_ISFZ, respectively (Figure 6, 2012). The second significant spat harvest took place on 24 September at the same sites but was characterized by lower abundances (45 and 21 ind. plate $^{-1}$ at Bouzigues_ISFZ and Listel_OSFZ, respectively). We also collected 34 ind. plate ${ }^{-1}$ at Balaruc_OSFZ on the same date. In 2013, one main spatfall event lasted for two consecutive harvests in August with 244 (13 August) and 341 (28 August) ind. plate ${ }^{-1}$ at Meze_OSFZ, 92 ind. plate ${ }^{-1}$ at Listel_OSFZ (28 August), and 188 (13 August) and 56 (28 August) ind. plate at $^{-1}$ at Bouzigues_ISFZ (Figure 6, 2013). There was a second, even bigger spatfall harvest (488 ind. plate $^{-1}$ ) that was only detected at Meze_OSFZ on 9 October. The most contrasted results inside and outside the shellfish farming sites were obtained in 2014, with spatfall occurring at all outside sites except Marseillan OSFZ for a period of two months (Figure 6, 2014). This period was characterized by four consecutive harvest dates between 13 August and 24 September 
versus no recruitment at all inside the shellfish farming areas. Meze_OSFZ showed the most remarkable spat abundances, peaking at 1112 ind. plate ${ }^{-1}$ on 27 August 2014.

The mean abundances of D-larvae (across all sampling dates and in all three years) differed significantly with the situation of ISFZ/OSFZ $(\mathrm{p}<0.0001)$ and were higher inside the shellfish farming zone $\left(7.05 \times 10^{4}\right.$ ind. $\left.\mathrm{m}^{-3}, \mathrm{n}=46\right)$ than outside $\left(7.02 \times 10^{3}\right.$ ind. $\left.\mathrm{m}^{-3}, \mathrm{n}=68\right)$ (Figure 7 a). By contrast, the mean abundances of large umbo larvae did not differ statistically $(\mathrm{p}>0.05)$ inside the shellfish farming zone $\left(1.11 \times 10^{2}\right.$ ind. $\left.\mathrm{m}^{-3}, \mathrm{n}=66\right)$ and outside $\left(0.89 \times 10^{2}\right.$ ind. $\mathrm{m}^{-3}$, $\mathrm{n}=79)$, and median values were also the same $\left(\sim 100\right.$ ind. $\left.\mathrm{m}^{-3}\right)$ (Figure $\left.7 \mathrm{~b}\right)$.

Mean abundances of pediveligers differed significantly $(\mathrm{p}<0.0001)$ inside and outside the shellfish farming zone (Figure 7c), but abundances were lower inside the shellfish farming zone (86 ind. plate ${ }^{-1}, \mathrm{n}=46$ ) than outside (881 ind. plate ${ }^{-1}, \mathrm{n}=68$ ). The mean oyster spat abundances were significantly lower inside $\left(\mathrm{p}<0.0001,9\right.$ ind. plate $\left.^{-1}, \mathrm{n}=72\right)$ than outside the shellfish farming zone (42 ind. plate ${ }^{-1}, \mathrm{n}=96$ ) (Figure 7d).

\subsection{Spatial patterns of simulated connectivity}

The spatial distributions of the connectivity index over the Thau lagoon (Figure 8) for passive tracers released over the oyster farming zones differed significantly depending on the sampling sites (Table $3, \mathrm{p}<0.001$ ). The connectivity index was low all along the margins of the lagoon and two gradients of increasing values (i) from inside to outside shellfish farming zone and (ii) from west to east elsewhere, with low interannual variability (Table 4).

There was significant difference between groups of sampling sites in the levels of connectivity with shellfish farming zone (analysis of variance model $\mathrm{p}<0.001$; Tukey contrasts multiple comparison tests, Table 4). The lowest mean connectivity (CI) was measured at the two most peripheral sites, Balaruc_OSFZ $\left(\mathrm{CI}=0.003 \mathrm{~d}^{-1}, \mathrm{n}=17\right)$ and Marseillan_OSFZ $\left(\mathrm{CI}=0.002 \mathrm{~d}^{-1}\right.$, 
$\mathrm{n}=17$ ) (Figure 9). By contrast, Bouzigues_ISFZ $\left(\mathrm{CI}=0.008 \mathrm{~d}^{-1}, \mathrm{n}=16\right)$ and Bouzigues_OSFZ $\left(\mathrm{CI}=0.009 \mathrm{~d}^{-1}, \mathrm{n}=6\right)$ had the highest connectivity values. The four remaining sites had intermediate connectivity levels, ranging from 0.004 to 0.007 , and were grouped differently (b, $\mathrm{c}, \mathrm{d}$ groups) by the multiple comparison test depending either on their location along the eastwest axis of the lagoon or whether they were located inside or outside the shellfish farming zones.

\subsection{Connectivity and larval supply}

When we linked observed larval abundances and the connectivity index inside or outside the shellfish farming zones, we found a non-significant relationship ( $p>0.05$, Table 5) between large umbo larvae abundance and connectivity inside and outside the zones (Figure 10a). The two eastern and western sides, Marseillan_OSFZ and Balaruc_OSFZ, had the lowest connectivity and the lowest abundances of large umbo larvae. There was a non-significant difference in the abundances of large umbo larvae with situation $(p>0.05$, Table 5) with very low depletion inside the shellfish farming zone compared to outside. In contrast, the interaction " connectivity Index: situation" was significant $(\mathrm{p}<0.005$, Table 6$)$ with a significant positive relationship between connectivity and pediveliger abundances outside shellfish farming zones ( $p<0.0001$, Table 6) while inside, this relationship was not significant (Figure 10b). Only two sites (Bouzigues_OSFZ and Marseillan_OSFZ) differed significantly from each other in large umbo larvae abundances (Table 7). The Bouzigues_OSFZ site was defined by high values of connectivity and by high mean abundances of pediveligers (Table 8, group e, 2291 ind. plate ${ }^{-}$ $\left.{ }^{1}\right)$. With a similar level of connectivity, the Bouzigues_ISFZ site had a mean abundance of pediveligers 70 times lower (group ac, Bouzigues_ISFZ= 28 ind. plate ${ }^{-1}$ ). The western sites Marseillan_ISFZ and Marseillan_OSFZ were characterized by low abundances of pediveligers (respectively, group a and ab, 17 ind. plate ${ }^{-1}$ and 28 ind. plate ${ }^{-1}$ ). In the central part of the lagoon, the pediveliger abundances were approximately 30 times higher at Listel_OSFZ than at 
Meze_ISFZ (group ab, 22.4 ind. plate $^{-1}$ ). A ratio of 70 was found between the pediveliger abundances at the site with the highest connectivity (Bouzigues_ISFZ) and at the site with the lowest connectivity (Marseillan OSFZ). Regarding intercepts of fitted regression models, sites inside the shellfish farming zone such as Bouzigues_ISFZ, Meze_ISFZ and Marseillan_ISFZ had significantly lower pediveliger abundances $\left(20\right.$ ind. plate $\left.^{-1}, \mathrm{p}<0.05\right)$ than sites outside $(204$ ind. plate $\left.{ }^{-1}, \mathrm{p}<0.001\right)$.

\subsection{Spatial variability of ecological parameters and interactions with pediveligers abundance}

The analysis of the multiple regression model linking the abundance of pediveligers to the variables of the planktonic environment explained $69 \%$ of the quality of the model fit (Table 9). A significant positive relation was found for abundances of cyanophycae (Figure 11a, p < 0.05), diatoms (Figure 11b, Table $9 \mathrm{p}<0.05$ ), heterotrophic flagellates (Figure 11c, Table $9 \mathrm{p}$ $<0.05$ ) nanophytoplankton (Figure 11d, Table $9 \mathrm{p}<0.05$ ). On the contrary, significant negative relation was found for abundances of picoeukaryotes (Figure 11e, Table $9 \mathrm{p}<0.05$ ) and tintinnidae (Figure 11f, Table $9 \mathrm{p}<0.001$ ).

More generally at lagoon scale, eight of the 26 monitored environmental variables (Table 1) differed significantly (Kruskall-Wallis tests, $\mathrm{p}<0.05$ ) at three sampling stations (Marseillan_ISFZ, Bouzigues_ISFZ and Listel_OSFZ): biomasses of pico + nanophytoplankton $(<20 \mu \mathrm{m})$, microphytoplankton $(>20 \mu \mathrm{m})$ and nanophytoplankton $(3-20$ $\mu \mathrm{m})$ and abundances of autotrophic picoeukaryotes, nanophytoplankton, Chaetoceros spp, mesozooplankton competitors and predators (Figure 12). Generally, abundances and biomasses were lowest at Marseillan_ISFZ, intermediate at Bouzigues_ISFZ and highest at Listel_OSFZ, except picoeukaryote abundances which were lowest at Listel_OSFZ. Significant differences were found in five of the 26 variables (pico + nanophytoplankton biomass, nanophytoplankton 
biomass, microphytoplankton biomass, Chaetoceros spp abundance and predators abundance) between the two ISFZ sites, with lower values at Marseillan than at Bouzigues. The averaged biomass of pico + nanophytoplankton, their averaged biomass at Marseillan_ISFZ was lower $\left(0.87 \pm 0.33 \mu \mathrm{gChla} \mathrm{l}^{-1}\right)$ than at Bouzigues_ISFZ $\left(1.14 \pm 0.45 \mu \mathrm{gChla} \mathrm{^{-1 }}\right)$ as nanophytoplankton Marseillan_ISFZ $\left(0.44 \pm 0.27 \mu \mathrm{gChla} \mathrm{l}^{-1}\right)$ and nanophytoplankton ${ }_{\text {Bouzigues_ISFZ }}$ $\left(0.71 \pm 0.37 \mu \mathrm{gChla}^{-1}\right)$ and microphytoplankton ${ }_{\text {Marseillan_ISFZ }}\left(0.29 \pm 0.25 \mu \mathrm{gChla}^{-1}\right)$ and microphytoplankton $_{\text {Bouzigues_ISFZ }}\left(0.82 \pm 0.51 \mu \mathrm{gChla} \mathrm{l}^{-1}\right)$. Abundances of Chaetoceros spp differed between Marseillan_ISFZ and Bouzigues_ISFZ with respectively $4.53 \times 10^{4} \pm 9.87 \times$ $10^{4}$ cell $^{-1}$ and $2.13 \times 10^{5} \pm 3.22 \times 10^{5}$ cell $^{1^{-1}}$. The contrasts between the sites inside and outside the shellfish farming zone were mainly expressed by the abundances of picoeukaryote, Chaetoceros spp, nanophytoplankton, competitors and predators. Abundances of picoeukaryote were similar at Marseillan_ISFZ $\left(3.6 \times 10^{7} \pm 2.1 \times 10^{7}\right.$ cell $\left.^{-1}\right)$ and Bouzigues_ISFZ $\left(3.4 \times 10^{7}\right.$ $\pm 1.7 \times 10^{7}$ cell $\left.1^{-1}\right)$ and almost double those at Listel_OSFZ $\left(1.8 \times 10^{7} \pm 0.9 \times 10^{7}\right.$ cell $\left.^{-1}\right)$. Chaetoceros spp were a highly abundant: $4.2 \times 10^{5} \pm 5.0 \times 10^{5}$ cell $1^{-1}$ at Listel_OSFZ, corresponding to two- and nine-fold higher abundance than that recorded at Bouzigues_ISFZ and at Marseillan_ISFZ, respectively. Nanophytoplankton were $30 \%$ more abundant at

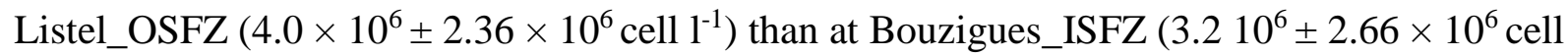
$1^{-1}$ ). Competitors were on average twice as abundant at OSFZ sites (competitorsListel_OSFZ $=36.1$ $\times 10^{3} \pm 28.5 \times 10^{3}$ ind. $\mathrm{m}^{-3}$ ) than at ISFZ (competitorsBouzigues_ISFZ $=18.6 \times 10^{3} \pm 12.8 \times 10^{3}$ ind. $\mathrm{m}^{-3}$ and competitorSMarseillan_ISFZ $=20.3 \times 10^{3} \pm 17.0 \times 10^{3}$ ind. $\mathrm{m}^{-3}$ ). Predator abundance was lower inside the shellfish farmed zone (predatorsMarseillan_ISFZ $=0.05 \pm 0.06$ ind. $\mathrm{m}^{-3}$; predatorsBouzigues_ISFZ $=0.19 \pm 0.22$ ind. $\mathrm{m}^{-3}$ ) than outside $\left(\right.$ predators Listel_OSFZ $_{-}=0.46 \pm$ 0.44 ind. $\left.\mathrm{m}^{-3}\right)$. 


\section{DISCUSSION}

The aim of this study was to evaluate the processes that drive spatial patterns of larval supply, settlement and recruitment of the Pacific oyster in a Mediterranean nanotidal semi-enclosed coastal lagoon. The results of the 3-year study revealed marked variability of observed oyster recruitment at the lagoon scale including high and low abundance of spat after collections. This variability reflects the ecological heterogeneity of Thau lagoon. In previous studies, Lagarde et al. $(2017,2018)$ showed that the temporal variability of recruitment was related to lagoon functioning driven by temperature and trophic inputs (abundance of nanophytoplankton and of Chaetoceros spp). The spatial heterogeneity measured in the present study suggests that different hydrodynamic and ecological processes occur simultaneously at sampling sites located in the east vs. west and inside vs. outside the shellfish farmed zones. The sampling sites located in the east and west parts of the lagoon showed the lowest recruitment while the spatial windows most favorable for recruitment were located in the center of the lagoon outside the shellfish farmed zone.

There is negligible wild Pacific oyster broodstock in the coastal Thau lagoon, thus larvae were mainly collected from reared oyster stock inside the shellfish farmed zones. We hypothesize that the restricted nanotidal lagoons promote larval retention due to the characteristics of the enclosed lagoon and that the nanotidal regime has limited effects. In this context, the emergence of D-larvae cohorts after adult spawning events determines the larval supply to the system. The abundances of D-larvae inside shellfish farming zones were higher than outside, confirming that the D-larvae came from the oyster rearing areas. The abundances of large umbo larvae were similar inside and outside shellfish farming zone, likely due to the combined effects of high larval retention and hydrodynamic currents, the driving forces of both dispersion and connectivity in Thau Lagoon. 
However, the temporal variability of the phenomenon is highlighted by the high maximum concentrations of large umbo larvae recorded in the Thau lagoon in 2010 and 2011 with respectively 6,100 larvae $\mathrm{m}^{-3}$ and 55,000 larvae $\mathrm{m}^{-3}$ (Rayssac et al. 2012), whereas in 2012, 2013 and 2014, the maximum concentrations reached only respectively 160, 450 and 27 larvae $\mathrm{m}^{-3}$. For the sake of comparison, in 2013, the maximum concentrations of large umbo larvae were 120 larvae $\mathrm{m}^{-3}$ in the Arcachon basin and 29 larvae $\mathrm{m}^{-3}$ in the Marennes-Oléron basin (Pouvreau 2013, 2014, 2015). In Thau lagoon, the supply of pelagic larvae was guaranteed by the high density of oyster broodstock (Gangnery et al. 2004) and the self-recruitment ability of the enclosed basin. Given the homogeneous high abundances of pelagic large umbo larvae, we conclude that the abundance of pelagic larvae is not a limiting factor for oyster recruitment in Thau lagoon.

In this study, the relatively homogeneous abundances of large umbo larvae inside and outside the shellfish farming zone also suggest the absence of intense larviphagy (Lehane \& Davenport 2004, Troost, Kamermans, et al. 2008, Troost, Veldhuizen, et al. 2008). Thus, although larviphagy probably exists in Thau lagoon, it had a minor effect on the variability of recruitment.

Larval dispersion through hydrodynamic circulation is considered to be as an important process in the recruitment of marine invertebrates (Levin 2006, LeCorre 2013, Ghezzo et al. 2015). The hydrodynamic circulation in coastal lagoons is strongly constrained by the borders, the bathymetry and the direction and intensity of the wind (Ghezzo et al. 2015, Fiandrino et al. 2017). Our simulation results concerning the connectivity indicator showed that, like the pearl oyster in a Pacific lagoon (Thomas et al., 2014), the distribution of the last pelagic larval stage (umbo larvae) in Thau lagoon tended to be spatially homogeneous. However, cumulative fluxes of tracers revealed significant differences in hydrodynamic connectivity among sites, depending on their location in the lagoon. Low hydrodynamic connectivity is usually found in 
highly confined sites (Guelorget et al. 1987, Guelorget \& Perthuisot 1992) like the western part of Thau lagoon, or areas under the influence of the sea like the eastern part of Thau lagoon. Indeed, the westernmost (Marseillan_OSFZ) and easternmost (Balaruc_OSFZ) sampling sites had the lowest simulated connectivity with oyster farming areas. Conversely, the two sampling sites characterized by the highest connectivity, Bouzigues_ISFZ and Bouzigues_OSFZ, are not only influenced by the main Bouzigues oyster zone, but are also located in a zone with preferential gyre patterns (Fiandrino et al. 2017). In a nanotidal restricted lagoon like Thau, gyre circulation is mainly driven by wind and constrained by topography (bathymetry and sinuosity) (Bernard et al. 2013, Fiandrino et al. 2017). In agreement with Perez-Ruzafa et al. (2018), our results show that the effects of hydrodynamic connectivity play a key role in the biological and community spatial structure of coastal lagoons.

Comparing simulated hydrodynamic connectivity with observed larval development makes it possible to identify and distinguish the role of hydrodynamics from that of ecological factors during the recruitment process. Overall, our results suggest that, at the large umbo stage, the larval supply was primarily structured by the presence of shellfish growing areas nearby, and then by hydrodynamics, with relative homogeneity in the center of the system (Lagarde et al. 2017, 2018). Inside the shellfish farming zone, our results suggest that the reduction in recruitment that occurred was due to loss of settlement competence at the pediveliger stage, leading to a dramatic average 10 -fold loss (up to 70 -fold) in pediveliger abundance per plate. The heterogeneity of the pediveliger supply can be explained on one hand by connectivity in the OSFZ sites and on the other hand by the effect of the location (inside vs. outside shellfish farming zone).

In a previous study, Lagarde et al. (2017) showed that over time, the abundance of pediveligers was driven by the abundance of specific trophic plankton such as the diatoms; Chaetoceros spp in this ecosystem, supporting the hypothesis of the trophic settlement trigger (Toupoint et al. 
2012). In the present study, significant spatial differences in phytoplankton abundance and biomass were detected between shellfish farming sites Bouzigues_ISFZ in the eastern part of the lagoon and Marseillan_ISFZ in the western part. This east-west gradient was shown to be due to nutrient inputs (the main inputs come from perennial rivers entering the lagoon in the east) (Jarry et al. 1990, Plus et al. 2006) and was amplified by the filter-feeders trophic depletion of phytoplankton biomass, with 1.7-fold more nanophytoplankton and 2.8-fold more microphytoplankton at the eastern site of Bouzigues_ISFZ than at the western site of Marseillan_ISFZ. Similarly, regarding phytoplankton abundance, almost five times more Chaetoceros spp were counted at Bouzigues_ISFZ than at Marseillan_ISFZ. The contrast between inside and outside the shellfish farmed zone was underlined by twice as many picoeukaryote counted inside than outside. Abundances of Chaetoceros spp were twice as high at Listel_OSFZ, than at Bouzigues_ISFZ and 9-fold higher at Marseillan_ISFZ. Nanophytoplankton were 30\% more abundant at Listel_OSFZ than inside the shellfish farming zone. As we showed a positive effect of cyanophycae, diatoms, heterotrophic flagellates and nanophytoplankton on pediveligers abundance, we hypothesize that the loss of settlement competence of pediveligers inside the oyster rearing zones is linked to the depletion of food resources, i.e. nanophytoplankton and diatoms, thereby reducing the effect of the trophic settlement trigger. A decrease in the abundance of oyster spat was observed both inside and outside the shellfish farming zones compared to the abundance of pediveligers, suggesting a low survival rate at metamorphosis both inside and outside the shellfish farming zone. We previously showed that survival at metamorphosis was positively correlated with nanophytoplankton abundance (Lagarde et al. 2017). Other authors demonstrated that the presence of shellfish results in a decrease in zooplankton and phytoplankton, biomasses with deficits of 30 and 40\% respectively (Lam-Hoai et al. 1997, Souchu et al. 2001, Bec et al. 2005). In line with these results, we observed that nanophytoplankton abundance was lower inside the 
shellfish farming zone than outside. This depletion is due to trophic filtration (top-down control inside the shellfish farming zones) of adult shellfish, including oysters (Deslous-Paoli et al. 1993, Pernet et al. 2012, Lagarde et al. 2017), with an indirect impact on pediveliger abundances, metamorphosis survival and spat abundance. We therefore conclude that feeding constraints during sensitive stages such as settlement and metamorphosis were responsible for the heterogeneous recruitment observed at the scale of the whole lagoon.

Zooplanktonic trophic competitors and potential predators in the water column mirrored the population dynamics of autotrophic prey and that of the oyster larvae without significantly or negatively impacting oyster recruitment (Lagarde et al. 2017). In our previous study, we showed there was no negative correlation between recruitment and the abundance of predators and/or competitors. In the case of competitors, our results suggest that their abundances are lower inside the shellfish farming zone than outside because the filtration pressure of the adult oysters exerts top-down control of the trophic chain.

Our results suggest that the destructuring of the supply of pediveligers is due to lack of food (trophic competition, and lack of energy) or unsuitable food (tintinnids, picoeukaryotes) leading to energy deficient larvae.

In the case of picoeukaryotes, abundances at the two sites inside shellfish farming zones, Marseillan_ISFZ and Bouzigues_ISFZ were higher than outside at Listel_OSFZ. This suggests that while filter feeders (such as oysters and mussels in the farms) affect the biomass and abundance of nano and microplankton, they have much less impact on picoplankton, as they are not able to directly retain the smaller particles (Vaquer et al. 1996, Dupuy et al. 2000, Lefebvre et al. 2000). Moreover picoplankton abundances increase through a feedback loop i.e. the excretion of cultured bivalves favors the microbial loop based on smaller phytoplankton (Bec et al. 2005) and provides for top-down trophic control inside the shellfish farming zone (Lagarde et al. 2017, 2018). Top-down trophic control has already been hypothesized based on 
observed spatial depletion of plankton including secondary producers (Lam-Hoai et al. 1997), or by comparing different shellfish exploited areas over time (Lagarde et al. 2017, 2018). Some complementary diagnoses provided by the "median lagoon-scale depletion index" based on modeling carrying capacity (Filgueira et al. 2014) revealed negative values of the index in summer and at the beginning of autumn (Pete et al. submitted). These authors used Dame's index (Dame \& Prins 1998) based on excess primary production integrated over the year to demonstrate the direct influence of shellfish farming on phytoplankton resources inside the shellfish farming zone. Regarding Thau lagoon, the production of shellfish appeared to be negatively correlated with the depletion index (Pete et al. Submitted).

Our hypothesis that oyster larvae inside the shellfish farmed zone of Thau lagoon suffer from food depletion challenges the claim that food limitation is seldom important for invertebrate larvae (Olson \& Olson 1989). These authors argued that food limitation is more common in the open ocean than in near shore waters. Our results suggest that bivalve recruitment in coastal lagoons is negatively impacted by trophic competition during trophic top down control in summer, particularly in the case of highly exploited shellfish farming ecosystem under oligotrophication process.

Successful recruitment of juveniles to an existing bivalve population depends on substrate preferences and interspecific interactions. To standardize our collection, sampling sites were all equipped with the same type of plate collectors (coupelles) to enable us to compare intra-lagoon and inter-basin recruitment particularly in the framework of the French Oyster Larvae Monitoring Network(Pouvreau 2018). Spat collection on collector plates differs from natural recruitment. In particular, it is not certain that predators have the same access to spat on collector plates as on natural substrate. After recruitment (as defined here), the interspecific interactions that take place on the collectors have a strong effect on benthic assemblages. The next step will be to characterize benthic assemblages to define the type of interaction (predation, 
trophic or territorial competition) using a probabilistic model of species co-occurrence (Veech 2013, Griffith et al. 2016) and to obtain more details on the functioning of the ecosystem in the context of oligotrophication and global climate change. This approach will also make it possible to qualify ecological functions such as "oyster nursery" in Thau lagoon.

This study of the spatial patterns of recruitment and connectivity completes the recent discovery of oyster spatfields in Thau lagoon (Lagarde et al. 2017, 2018). Confirmation of spatfields outside shellfish growing areas in this ecosystem with levels of collection never measured to date, opens new prospects for nurseries of locally born Pacific oyster juveniles. In the context of climate change, the challenge will be to help the bivalve sectors reduce their environmental footprint as suggested by Aubin et al. (2018), improvement still have to be proposed on energy demand to reduce i.e. the fuel consumption linked to transport. One way to achieve this goal is to promote and select local strains of cupped oyster that are better adapted to the local farming ecosystem. Another advantage of local development is reducing risks associated with transfer, moving shellfish within and between countries and ecosystems implies a high risk of ecological impacts (ICES 2011). Along with the target shellfish, transfers can introduce associated organisms (e.g. non-indigenous species, fouling organisms), potentially toxic algae, pathogens (viruses, bacteria, parasites) or same species with a different genetic makeup (Brenner et al. 2014, Carnegie et al. 2016). Local alternatives e.g. hatcheries or spat collection methods should be investigated before consideration of transfers as a last resort (Brenner et al. 2014).

The method we presented in this paper could be transposed to other basins or other species such as clams, mussels or scallops to better understand the spatial patterns of oyster recruitment or more globally bivalve recruitment, to improve their collection, and to draw up recommendations to enable the industrial sector to develop a sustainable activity. It could be integrated in Marine Spatial Planning tools designed to explore shellfish carrying capacity (Filgueira et al. 2015, Bacher et al. 2019). These scientific inputs should prove useful in 
supporting the blue economic development of a marine culture sector through the righteous practice of natural oyster collection according to sustainable uses in an ecosystem currently undergoing oligotrophication, ecological restoration and global change.

\section{Acknowledgements}

The authors thank the funders of the project "PRONAMED 2": France-Agrimer, Conseil Régional d'Occitanie/Languedoc-Roussillon, Conseil départemental de l'Hérault, Comité Régional de la Conchyliculture en Méditerranée, Cepralmar and Ifremer. F.L. and T.G. thank the RECHAGLO international research group for encouragement, support, and exchanges with Canada. Our special thanks to Adeline Perignon, Erika Gervasoni, Hélène Cochet and CochetEnvironnement, Jean-Louis Guillou, Patrik Le Gall, Gregory Messiaen, Marine Fuhrmann, Marie Boj, Slem Meddah, Solen Soriano and Axel Leurion for their assistance, their involvement and commitment during field and laboratory work. The authors also thank Luke Poirier, a native English scientific researcher, for proof reading our manuscript. 


\section{References}

Arakawa KY (1990) Competitors and fouling organisms in the hanging culture of the pacific oyster, Crassostrea gigas (Thunberg). Mar Behav Physiol 17:67-94

Aubin J, Fontaine C, Callier M, Roque d'orbcastel E (2018) Blue mussel (Mytilus edulis) bouchot culture in Mont-St Michel Bay: potential mitigation effects on climate change and eutrophication. Int J Life Cycle Assess 23:1030-1041

Bacher C, Gangnery A, Cugier P, Mongruel R, Strand O, Frangoudes K (2019) Spatial, Ecological and Social Dimensions of Assessments for Bivalve Farming Management. Chap.26. In: Smaal A., Ferreira J., Grant J., Petersen J., Strand Ø. (eds) Goods and Services of Marine Bivalves. Springer, Cham. ISBN 978-3-319-96775-2, ISBN 978-3-319-967769 (eBook) https://doi.org/10.1007/978-3-319-96776-9. France, Norway, p 527-549

Bayne BL (2017) Biology of Oysters, Developments in Aquaculture and Fisheries Science. (Elsevier, Ed.), Academic P. Volume 41, London

Bec B, Husseini-Ratrema J, Collos Y, Souchu P, Vaquer A (2005) Phytoplankton seasonal dynamics in a Mediterranean coastal lagoon: Emphasis on the picoeukaryote community. J Plankton Res 27:881-894

Bernard J-P, Frenod E, Rousseau A (2013) Modeling confinement in Etang de Thau: numerical simulations and multi-scale aspects. Dyn Syst Differ Equations DCDS Suppl:pp.69-76

Booth DJ, Brosnan DM (1995) The Role of Recruitment Dynamics in Rocky Shore and Coral Reef Fish Communities. Adv Ecol Res 26:309-385

Brenner M, Fraser D, Nieuwenhove K Van, O’Beirn F, Buck BH, Mazurié J, Thorarinsdottir G, Dolmer P, Sanchez-Mata A, Strand O, Flimlin G, Miossec L, Kamermans P (2014) Bivalve aquaculture transfers in Atlantic Europe. Part B: Environmental impacts of transfer activities. Ocean Coast Manag 89:139-146

Bryan-Brown DN, Brown CJ, Hughes JM, Connolly RM (2017) Patterns and trends in marine 
population connectivity research. Mar Ecol Prog Ser 585:243-256

Carnegie RB, Arzul I, Bushek D (2016) Managing marine mollusc diseases in the context of regional and international commerce: Policy issues and emerging concerns. Philos Trans R Soc B Biol Sci 371

Collos Y, Bec B, Jauzein C, Abadie E, Laugier T, Lautier J, Pastoureaud A, Souchu P, Vaquer A (2009) Oligotrophication and emergence of picocyanobacteria and a toxic dinoflagellate in Thau lagoon, southern France. J Sea Res 61:68-75

Coon SL, Fitt WK, Bonar DB (1990) Competence and delay of metamorphosis in the Pacific oyster Crassostrea gigas. Mar Biol 106:379-387

Cowen R, Gawarkiewicz G, Pineda J, Thorrold SR, Werner F (2007) Population Connectivity in Marine Systems. Oceanography 20:14-21

Cowen RK, Sponaugle S (2009) Larval Dispersal and Marine Population Connectivity. In: Annual Review of Marine Science.p 443-466

Dame RF, Prins TC (1998) Bivalve carrying capacity in coastal ecosystems. Aquat Ecol 31:409-421

Deslous-Paoli JM, Mazouni N, Souchu P, Landrein S, Pichot P, Juge C (1993) Oyster Farming Impact on the Environment of a Mediterranean Lagoon (THAU). In: Dame RF (ed) Bivalve Filter Feeders: in Estuarine and Coastal Ecosystem Processes. Springer, Berlin, p $519-521$

Dupuy C, Vaquer A, Lam-Höai T, Rougier C, Mazouni N, Lautier J, Collos Y, Gall S Le (2000) Feeding rate of the oyster Crassostrea gigas in a natural planktonic community of the Mediterranean Thau lagoon. Mar Ecol Prog Ser 205:171-184

Elsäßer B, Fariñas-Franco JM, Wilson CD, Kregting L, Roberts D (2013) Identifying optimal sites for natural recovery and restoration of impacted biogenic habitats in a special area of conservation using hydrodynamic and habitat suitability modelling. J Sea Res 77:11-21 
Fiandrino A, Ouisse V, Dumas F, Lagarde F, Pete R, Malet N, Noc S Le, Wit R de (2017) Spatial patterns in coastal lagoons related to the hydrodynamics of seawater intrusion. Mar Pollut Bull 119:132-144

Filgueira R, Guyondet T, Bacher C, Comeau LA (2015) Informing Marine Spatial Planning (MSP) with numerical modelling: A case-study on shellfish aquaculture in Malpeque Bay (Eastern Canada). Mar Pollut Bull 100:200-216

Filgueira R, Guyondet T, Comeau L a., Grant J (2014) A fully-spatial ecosystem-DEB model of oyster (Crassostrea virginica) carrying capacity in the Richibucto Estuary, Eastern Canada. J Mar Syst 136:42-54

Fitt WK, Coon SL, Walch M, Weiner RM, Colwell RR, Bonar DB (1990) Settlement behavior and metamorphosis of oyster larvae (Crassostrea gigas) in response to bacterial supernatants. Mar Biol 106:389-394

Gaines S, Brown S, Roughgarden J (1985) Spatial Variation in Larval Concentrations as a Cause of Spatial Variation in Settlement for the Barnacle, Balanus glandula. Oecologia 67:267-272

Gangnery A, Bacher C, Buestel D (2004) Modelling oyster population dynamics in a Mediterranean coastal lagoon (Thau, France): Sensitivity of marketable production to environmental conditions. Aquaculture 230:323-347

Ghezzo M, Pascalis F De, Umgiesser G, Zemlys P, Sigovini M, Marcos C, Pérez-Ruzafa A (2015) Connectivity in Three European Coastal Lagoons. Estuaries and Coasts 38:17641781

Griffith DM, Veech JA, Marsh CJ (2016) cooccur: Probabilistic Species Co-Occurrence Analysis in $R$. J Stat Softw 69:1-17

Guelorget O, Perthuisot JP (1992) Paralic Ecosystems. Biological organization and functionning. Vie Milieu 42:215-251 
Guelorget O, Perthuisot J, Frisoni GF, Monti D (1987) Le rôle du confinement dans l'organisation biogéologique de la lagune de Nador (Maroc). Oceanol acta 10:435-444

Holgate SJ, Matthews A, Woodworth PL, Rickards LJ, Tamisiea ME, Bradshaw E, Foden PR, Gordon KM, Jevrejeva S, Pugh J (2013) New Data Systems and Products at the Permanent Service for Mean Sea Level. J Coast Res 288:493-504

Hori M, Hamaoka H, Hirota M, Lagarde F, Vaz S, Hamaguchi M, Hori J, Makino M, Hamaguchi M, Hori J, Makino M (2017) Application of the coastal ecosystem complex concept toward integrated management for sustainable coastal fisheries under oligotrophication. Fish Sci 84:283

Hunt HL, Scheibling RE (1997a) Role of early post-settlement mortality in recruitment of benthic marine invertebrates. Mar Ecol Prog Ser 155:269-301

Hunt HL, Scheibling RE (1997b) Recruitment of Benthic Marine Invertebrates. Mar Ecol Prog Ser 155:269-301

ICES (2011) International council for the exploration of the sea. In: Report of the Working Group on Marine Shellfish Culture (WGMASC), 5e8 April 2011, La Trinité-sur-Mer, France, p. 98 .

Jarry V, Fiala M, Frisoni GF, Jacques G, Neveux J, Panouse M (1990) The spatial distribution of phytoplankton in a Mediterranean lagoon (Etang de Thau). Oceanol Acta 13:503-512

Keough MJ, Downes BJ (1982) Recruitment of marine invertebrates: the role of active larval choices and early mortality. Oecologia 54:348-352

Kjerfve B (1994) Coastal Lagoons. Kjerfve Coast lagoon Process Elseviers:p 1-8

Lagarde F, Fiandrino A, Richard M, Bernard I, Mortreux S, Ubertini M, Chiantella C, Boj M, Meddah S, Leurion A, Soriano S, Fuhrmann M, Gall P Le, Berteaux T, Guillou J-L, Perignon A, Bonnet D, Roques C, Bec B, Cochet Hélène, Miron G, Pouvreau S, Roque D’Orbcastel E (2015) Déterminisme du recrutement larvaire de l'huître creuse 
Crassostrea gigas dans la lagune de Thau. RST ODE/UL/LERLR 2015-26. 45 p. http://archimer.ifremer.fr/doc/00279/39054/.

Lagarde F, Richard M, Bec B, Roques C, Mortreux S, Bernard I, Chiantella C, Messiaen G, Nadalini J-B, Hori M, Hamaguchi M, Pouvreau S, Roque d'Orbcastel E, Tremblay R (2018) Trophic environments influence size at metamorphosis and recruitment performance of the Pacific oyster. Mar Ecol Prog Ser 602:135-153

Lagarde F, Roque E, Ubertini M, Mortreux S, Bernard I, Fiandrino A, Chiantella C, Bec B, Roques C, Bonnet D, Miron G, Richard M, Pouvreau S, Lett C (2017) Recruitment of the Pacific oyster Crassostrea gigas in a shellfish-exploited Mediterranean lagoon : discovery , driving factors and a favorable environmental window. Mar Ecol Prog Ser 578:1-17

Lagarde F, Ubertini M, Mortreux S, Perignon A, Leurion A, Gall P Le, Chiantella C, Meddah S, Guillou J-L, Messiaen G, Bec B, Roques C, Bonnet D, Cochet H, Bernard I, Gervasoni E, Richard M, Miron G, Fiandrino A, Pouvreau S, Roque'orbcastel E (2019) Heterogeneity of Japanese Oyster (Crassostrea Gigas) Spat Collection in a Shellfish Farmed Mediterranean Lagoon. In: Komatsu T, Ceccaldi H-J, Yoshida J, Prouzet P, Henocque Y (eds) Oceanography Challenges to Future Earth, Human and Natural Impacts on our Seas. Proceedings., Springer N. Springer Nature-SFJO, p 341-350

Lam-Hoai T, Rougier C, Lasserre G (1997) Tintinnids and rotifers in a northern Mediterranean coastal lagoon. Structural diversity and function through biomass estimations. Mar Ecol Prog Ser 152:13-25

Lazure P, Dumas F (2008) An external-internal mode coupling for a 3D hydrodynamical model for applications at regional scale (MARS). Adv Water Resour 31:233-250

LeCorre N (2013) Variabilité de la connectivité et du recrutement au sein d'une métapopulation marine. Thesis Laval/Québec/Canada. 137 p

Lefebvre S, Barille L, Clerc M (2000) Pacific oyster Crassostrea gigas feeding responses to a 
fish-farm effluent. Aquaculture 187:185-198

Lehane C, Davenport J (2004) Ingestion of bivalve larvae by Mytilus edulis: experimental and field demonstrations of larviphagy in farmed blue mussels. Mar Biol 145

Levin L a. (2006) Recent progress in understanding larval dispersal: New directions and digressions. Integr Comp Biol 46:282-297

Olson RR, Olson MH (1989) Food Limitation of Planktotrophic Marine Invertebrate Larvae: Does it Control Recruitment Success? Annu Rev Ecol Syst 20:225-247

Pawlik JR (1992) Chemical ecology of the settlement of benthic marine marine-invertebrates. Oceanogr Mar Biol 30:273-335

Pechenik JA (2006) Larval experience and latent effects - Metamorphosis is not a new beginning. Integr Comp Biol 46:323-333

Pérez-Ruzafa A, Pascalis F De, Ghezzo M, Quispe-Becerra JI, Hernández-García R, Muñoz I, Vergara C, Pérez-Ruzafa IM, Umgiesser G, Marcos C (2018) Connectivity between coastal lagoons and sea: Asymmetrical effects on assemblages' and population's structure. Estuar Coast Shelf Sci In press

Pernet F, Malet N, Pastoureaud A, Vaquer A, Quéré C, Dubroca L (2012) Marine diatoms sustain growth of bivalves in a Mediterranean lagoon. J Sea Res 68:20-32

Pineda J, Hare J, Sponaugle S (2007) Larval Transport and Dispersal in the Coastal Ocean and Consequences for Population Connectivity. Oceanography 20:22-39

Pineda J, Reyns N (2018) Larval Transport in the Coastal Zone: Biological and Physical Processes. In: Carrier T, Reitzel A, Heyland A (eds) Evolutionary Ecology of Marine Invertebrate Larvae, Oxford Uni. Oxford Univ

Pineda J, Reyns NB, Starczak VR (2009) Complexity and simplification in understanding recruitment in benthic populations. Popul Ecol 51:17-32

Plus M, Jeunesse I La, Bouraoui F, Zaldívar JM, Chapelle A, Lazure P (2006) Modelling water 
discharges and nitrogen inputs into a Mediterranean lagoon: Impact on the primary production. Ecol Modell 193:69-89

Pouvreau S (2015) Observer, Analyser et Gérer la variabilité de la reproduction et du recrutement de l'huître creuse en France: Le Réseau Velyger. Rapport annuel 2014. 57p. https://wwz.ifremer.fr/velyger/Rapports-Annuels/Annee-2014

Pouvreau S (2016) Observer, analyser et gérer la variabilité de la reproduction et du recrutement de l'huître creuse en France: Le Réseau Velyger, Rapport annuel 2015. R.INT.BREST RBE/PFOM/PI 2016-1. 55p. http://archimer.ifremer.fr/doc/00334/44533/. 55p. https://archimer.ifremer.fr/doc/00334/44533/

Pouvreau S (2018) Observer, Analyser et Gérer la variabilité de la reproduction et du recrutement de l'huître creuse en France: Le Réseau Velyger. Rapport annuel 2017. https://wwz.ifremer.fr/velyger/Rapports-Annuels/Annee-2017.

Pouvreau S, Bellec G, Souchu P Le, Queau I, Talarmain E, Alunno-Bruscia M, Auby I, Maurer D, And Others . (2013) Observer, Analyser et Gérer la variabilité de la reproduction et du recrutement de l'huître creuse en France: Le Réseau Velyger. Rapport annuel 2012. http://doi.org/10.13155/31091

Pouvreau S, Maurer D, Auby I, Lagarde F, Gall P Le, Cochet H, Bouquet A-L, Geay A, Mille D (2016) VELYGER Database: The Oyster Larvae Monitoring French Project. :http://doi.org/10.17882/41888

R Core Team (2015) R: A language and environment for statistical computing. R Foundation for Statistical Computing, Vienna, Austria. http://www.R-project.org/.

Rayssac N, Perignon A, Gervasoni E, Pernet F, LeGall P, Lagarde F (2012) Evaluation du potentiel d'approvisionnement naturel en naissains d'huîtres creuses en Méditerranée Rapport Final - Projet PRONAMED 2010-2011.

REPHY - French Observation and Monitoring program for Phytoplankton and Hydrology 
(2017) REPHY dataset - French Observation and Monitoring program for Phytoplankton and Hydrology in coastal waters. 1987-2016 Metropolitan data. SEANOE. http://doi.org/10.17882/47248.

Rodriguez SR, Ojeda FP, Inestrosa NC (1993) Settlement of benthic marine invertebrates. Mar Ecol Prog Ser 97:193-207

Rose M (1933) Copépodes pélagiques. In: Faune de France.

Roughgarden J, Gaines SD, Possingham H (1988) Recruitment Dynamics in Complex life Cycles. Science (80- ) 241:1461-1466

Smyth D, Kregting L, Elsäßer B, Kennedy R, Roberts D (2016) Using particle dispersal models to assist in the conservation and recovery of the overexploited native oyster (Ostrea edulis) in an enclosed sea lough. J Sea Res 108:50-59

Souchu P, Bec B, Smith VH, Laugier T, Fiandrino A, Benau L, Orsoni V, Collos Y, Vaquer A (2010) Patterns in nutrient limitation and chlorophyll a along an anthropogenic eutrophication gradient in French Mediterranean coastal lagoons . Can J Fish Aquat Sci $67: 743-753$

Souchu P, Vaquer A, Collos Y, Landrein S, Deslous-Paoli JM, Bibent B (2001) Influence of shellfish farming activities on the biogeochemical composition of the water column in Thau lagoon. Mar Ecol Prog Ser 2018:141-152

Thomas Y, Dumas F, Andrefouet S (2016) Larval connectivity of pearl oyster through biophysical modelling; evidence of food limitation and broodstock effect. Estuar Coast Shelf Sci 182:283-293

Todd CD (1998) Larval supply and recruitment of benthic invertebrates : do larvae always disperse as much as we believe ? Hydrobiologia 375/376:1-21

Toupoint N, Gilmore-Solomon L, Bourque F, Myrand B, Pernet F, Olivier F, Tremblay R (2012) Match/mismatch between the Mytilus edulis larval supply and seston quality: effect 
on recruitment. Ecology 93:1922-1934

Troost K, Kamermans P, Wolff WJ (2008) Larviphagy in native bivalves and an introduced oyster. J Sea Res 60:157-163

Troost K, Veldhuizen R, Stamhuis EJ, Wolff WJ (2008) Can bivalve veligers escape feeding currents of adult bivalves? J Exp Mar Bio Ecol 358:185-196

Vaquer A, Troussellier M, Courties C, Bibent B (1996) Standing stock and dynamics of picophytoplankton in the Thau Lagoon (northwest Mediterranean coast). Limnol Oceanogr 41:1821-1828

Veech JA (2013) Macroecological methods. A probabilistic model for analysing species cooccurrence. Glob Ecol Biogeogr 22:252-260

Wing SR, Botsford LW, Morgan LE, Diehl JM, Lundquist CJ (2003) Inter-annual variability in larval supply to populations of three invertebrate taxa in the northern California Current. Estuar Coast Shelf Sci 57:859-872 
Table 1: Variables characterizing the interactions between the environment and Pacific oyster larvae at the sampling sites Bouzigues_ISFZ, Marseillan_ISFZ and Listel_OSFZ monitored from June to the end of September 2012, 2013 and 2014 (except Listel_OSFZ in 2012). Each environmental variable was averaged over a 22 day period preceding retrieval of the collectors. Superscript A: abundance; B: biomass. - means no transformation or no abbreviation.

\begin{tabular}{|c|c|c|c|c|}
\hline Variables & Description & Unity & Transformation & Abbreviation \\
\hline $\begin{array}{l}\text { Target variables } \\
\text { oyster spat }\end{array}$ & abundance & ind. plate ${ }^{-1}$ & $\begin{array}{c}\log _{10}(x+1) \text { or power Box- } \\
\text { Cox }(\text { lambda }=-0.63)\end{array}$ & $\begin{array}{l}\text { log_spat or } \\
\text { pbc_spat }\end{array}$ \\
\hline pediveligers & abundance & ind. plate ${ }^{-1}$ & $\log _{10}(x+1)$ & log_pedi \\
\hline $\begin{array}{l}\text { Environmental variables } \\
\text { connectivity Index } \\
\text { max D-larvae }\end{array}$ & $\begin{array}{l}\text { Daily ratio } \\
\text { maximum D- } \\
\text { larvae abundance }\end{array}$ & $\begin{array}{c}\% \mathrm{~d}^{-1} \\
\text { ind. } \mathrm{m}^{-3}\end{array}$ & $\log _{10}(x+1)$ & log_max_DL \\
\hline max large umbo larvae & $\begin{array}{lr}\text { Maximum } & \text { large } \\
\text { umbo } & \text { larvae } \\
\text { abundance } & \end{array}$ & ind. $\mathrm{m}^{-3}$ & $\log _{10}(x+1)$ & log_max_UL \\
\hline temperature & daily average & ${ }^{\circ} \mathrm{C}$ & - & - \\
\hline salinity & daily average & No unit & - & - \\
\hline bacteria & abundance & $10^{6}$ cell. $1^{-1}$ & $\log _{10}(x+1)$ & $\log _{\text {bact }} \mathrm{A}^{\mathrm{A}}$ \\
\hline $\begin{array}{l}\text { autotrophic } \\
\text { picoeukaryotes }\end{array}$ & abundance & $10^{6}$ cell. $1^{-1}$ & $\log _{10}(x+1)$ & log_peuk_tot ${ }^{A}$ \\
\hline picocyanobacteria & abundance & $10^{6}$ cell. $1^{-1}$ & $\log _{10}(x+1)$ & $\log$ cyan ${ }^{A}$ \\
\hline picophytoplankton & abundance & $10^{6}$ cell. $1^{-1}$ & $\log _{10}(x+1)$ & log_pico_tot ${ }^{\mathrm{A}}$ \\
\hline nanophytoplankton & abundance & $10^{6}$ cell. $1^{-1}$ & $\log _{10}(x+1)$ & $\log \_$nano ${ }^{A}$ \\
\hline cryptophycae & abundance & $10^{6}$ cell. $1^{-1}$ & $\log _{10}(x+1)$ & log_crypto ${ }^{A}$ \\
\hline $\begin{array}{l}\text { nanophytoplankton } \\
\text { cryptophycae }\end{array}$ & abundance & $10^{6}$ cell. $1^{-1}$ & $\log _{10}(x+1)$ & log_nano_tot ${ }^{\mathrm{A}}$ \\
\hline heterotrophic flagellates & abundance & cell $1^{-1}$ & $\log _{10}(x+1)$ & $\log \_H F^{A}$ \\
\hline naked ciliates & abundance & cell $1^{-1}$ & $\log _{10}(x+1)$ & $\log$ ciliates $^{\mathrm{A}}$ \\
\hline tintinnidae & abundance & cell $1^{-1}$ & $\log _{10}(x+1)$ & $\log$ tinti $^{\mathrm{A}}$ \\
\hline diatoms & abundance & cell $1^{-1}$ & $\log _{10}(x+1)$ & $\log _{\text {diatom }}{ }^{\mathrm{A}}$ \\
\hline dinoflagellates & abundance & cell $1^{-1}$ & $\log _{10}(x+1)$ & log_dinoflagellates ${ }^{\mathrm{A}}$ \\
\hline Chaetoceros & abundance & cell $1^{-1}$ & $\log _{10}(x+1)$ & $\log _{\text {_chaetoceros }}{ }^{\mathrm{A}}$ \\
\hline total chlorophyll $a$ & biomass & $\mu \mathrm{gChla}^{-1}$ & $\log _{10}(x+1)$ & log_total_chloa ${ }^{\mathrm{B}}$ \\
\hline picophytoplankton & biomass & $\mu \mathrm{gChla}^{-1}$ & $\log _{10}(x+1)$ & $\log \_p i c o^{B}$ \\
\hline nanophytoplankton & biomass & $\mu \mathrm{gChla}^{-1}$ & $\log (x)$ & log_nano_3_20 \\
\hline $\begin{array}{l}\text { picophytoplankton+ } \\
\text { nanophytoplankton }\end{array}$ & biomass & $\mu \mathrm{gChla}^{-1}$ & $\log _{10}(x+1)$ & log_nano_low $20^{\mathrm{B}}$ \\
\hline $\begin{array}{l}\text { microphytoplankton } \\
\text { larger than } 20 \mu \mathrm{m}\end{array}$ & biomass & $\mu g 1^{-1}$ & $\log _{10}(x+1)$ & log_micro ${ }^{B}$ \\
\hline competitors & abundance & ind. $\mathrm{m}^{-3}$ & square $\operatorname{root}(\mathrm{x})$ & sqrt_comp ${ }^{\mathrm{A}}$ \\
\hline predators & abundance & ind. $\mathrm{m}^{-3}$ & $\log _{10}(x+1)$ & log_pred ${ }^{\mathrm{A}}$ \\
\hline
\end{tabular}


Table 2: Analysis of variance examining the effect of years, situations (inside or outside the shellfish farming area) and sampling sites on Pacific oyster spat abundance per plate (power Box-Cox transformation; lambda $=-0.63, \mathrm{n}=168)$. Significant values in bold $(\mathrm{p}<0.05)$.

\begin{tabular}{|rccccc|}
\hline \multicolumn{1}{|c|}{ Anova Table } & Df & Sum Sq & Mean Sq & $\begin{array}{c}\mathbf{F} \\
\text { value }\end{array}$ & $\operatorname{Pr}(>\mathbf{F})$ \\
\hline Situation & 1 & 2.44 & 2.44 & 8.474 & $\mathbf{p}<\mathbf{0 . 0 1}$ \\
Site & 6 & 3.99 & 0.66 & 2.305 & $\mathbf{p}<\mathbf{0 . 0 5}$ \\
Year & 2 & 0.05 & 0.02 & 0.081 & 0.922 \\
Situation:Year & 2 & 2.06 & 1.03 & 3.572 & $\mathbf{p}<\mathbf{0 . 0 5}$ \\
Site:Year & 9 & 3.71 & 0.41 & 1.432 & 0.179 \\
Residuals & 147 & 42.36 & 0.28 & & \\
\hline & & & & &
\end{tabular}


Table 3: Analysis of variance model examining the effect of sampling sites on the connectivity index. Significant values are in bold $(\mathrm{p}<0.05)$

\begin{tabular}{|rccccc|}
\hline Anova Table & Df & Sum Sq & Mean Sq & $\begin{array}{c}\text { F } \\
\text { value }\end{array}$ & Pr(>F) \\
\hline site & 7 & 0.0005 & 0.00007 & 57.76 & $\mathbf{p}<\mathbf{0 . 0 0 1}$ \\
Residuals & 106 & 0.0001 & 0.000001 & & \\
\hline & & & & &
\end{tabular}


Table 4: Simultaneous Tests for General Linear Hypotheses with Tukey Contrasts Multiple Comparisons of Means, fitted on an analysis of variance model to examine the effect of sampling sites on the connectivity index. p-values in bold are significant at the $95 \%$ confidence level.

\begin{tabular}{|c|c|c|c|c|}
\hline Linear Hypotheses: & Estimate & Std Error & T value & $\operatorname{Pr}(>\mathrm{T})$ \\
\hline marseillan_ISFZ - marseillan_OSFZ $==0$ & 0.00378 & 0.0004 & 9.686 & $<0.001$ \\
\hline listel_OSFZ - marseillan_OSFZ $==0$ & 0.00436 & 0.0004 & 11.341 & $<0.001$ \\
\hline meze_ISFZ - marseillan_OSFZ $==0$ & 0.00198 & 0.0004 & 5.144 & $<0.001$ \\
\hline meze_OSFZ - marseillan_OSFZ $==0$ & 0.00265 & 0.0004 & 6.297 & $<0.001$ \\
\hline bouzigues_OSFZ - marseillan_OSFZ $==0$ & 0.00656 & 0.0005 & 12.395 & $<0.001$ \\
\hline bouzigues_ISFZ - marseillan_OSFZ $==0$ & 0.00578 & 0.0004 & 14.019 & $<0.001$ \\
\hline balaruc_OSFZ - marseillan_OSFZ $==0$ & 0.00038 & 0.0004 & 1.004 & 0.9722 \\
\hline listel_OSFZ - marseillan_ISFZ $==0$ & 0.00058 & 0.0004 & 1.510 & 0.7970 \\
\hline meze_ISFZ - marseillan_ISFZ $==0$ & -0.0018 & 0.0004 & -4.688 & $<0.001$ \\
\hline meze_OSFZ - marseillan_ISFZ $==0$ & -0.0011 & 0.0004 & -2.671 & 0.1402 \\
\hline bouzigues_OSFZ - marseillan_ISFZ $==0$ & 0.0028 & 0.0005 & 5.242 & $<0.001$ \\
\hline bouzigues_ISFZ - marseillan_ISSFZ $==0$ & 0.0020 & 0.0004 & 4.847 & $<0.001$ \\
\hline balaruc_OSFZ - marseillan_ISFZ $==0$ & 0.0034 & 0.0004 & -8.828 & $<0.001$ \\
\hline meze_ISFZ - listel_OSFZ $==0$ & -0.0024 & 0.0004 & -6.293 & $<0.001$ \\
\hline meze_OSFZ - listel_OSFZ $==0$ & -0.0017 & 0.0004 & -4.100 & 0.0018 \\
\hline bouzigues_OSFZ - listel_OSFZ $==0$ & 0.0022 & 0.0005 & 4.177 & 0.0015 \\
\hline bouzigues_ISFZ - listel_OSFZ $==0$ & 0.0014 & 0.0004 & 3.485 & 0.0154 \\
\hline balaruc_OSFZ - listel_OSFZ $==0$ & -0.0040 & 0.0004 & -10.498 & $<0.001$ \\
\hline meze_OSFZ - meze_ISFZ $==0$ & 0.0007 & 0.0004 & 1.625 & 0.7296 \\
\hline bouzigues_OSFZ - meze_ISFZ $==0$ & 0.0046 & 0.0005 & 8.723 & $<0.001$ \\
\hline bouzigues_ISFZ - meze_ISFZ $==0$ & 0.0038 & 0.0004 & 9.344 & $<0.001$ \\
\hline balaruc_OSFZ - meze_ISFZ $==0$ & -0.0016 & 0.0004 & -4.205 & 0.0014 \\
\hline bouzigues_OSFZ - meze_OSFZ $==0$ & 0.0039 & 0.0005 & 7.058 & $<0.001$ \\
\hline bouzigues_ISFZ - meze_OSFZ $==0$ & 0.00312 & 0.0004 & 7.069 & $<0.001$ \\
\hline balaruc_OSFZ - meze_OSFZ $==0$ & -0.0023 & 0.0004 & -5.450 & $<0.001$ \\
\hline bouzigues_ISFZ - bouzigues_OSFZ $==0$ & -0.0008 & 0.0005 & -1.417 & 0.8444 \\
\hline balaruc_OSFZ - bouzigues_OSFZ $==0$ & -0.0062 & 0.0005 & -11.760 & $<0.001$ \\
\hline balaruc_OSFZ - bouzigues_ISFZ $==0$ & -0.0054 & 0.0004 & -13.258 & $<0.001$ \\
\hline
\end{tabular}


Table 5: ANCOVA table and summary examining the effect of the connectivity index and situation factors on large umbo larvae abundance ( $\log _{10}$ transform) in the water column. Significant values are in bold $(\mathrm{p}<0.05)$

\begin{tabular}{|c|c|c|c|c|c|}
\hline Ancova Table & Df & Sum Sq & Mean Sq & $\begin{array}{c}\mathbf{F} \\
\text { value }\end{array}$ & $\operatorname{Pr}(>\mathbf{F})$ \\
\hline Connectivity Index & 1 & 1.093 & 1.093 & 2.586 & 0.110 \\
\hline Situation & 1 & 0.894 & 0.894 & 2.114 & 0.148 \\
\hline Connectivity Index:Situation & 1 & 0.072 & 0.072 & 0.171 & 0.680 \\
\hline Residuals & 141 & 59.612 & 0.423 & & \\
\hline \multicolumn{2}{|l|}{ Ancova Summary } & Estimate & Std Error & $\begin{array}{c}\mathbf{T} \\
\text { value }\end{array}$ & $\operatorname{Pr}(>\mathbf{T})$ \\
\hline \multicolumn{2}{|l|}{ (Intercept) } & 2.007 & 0.276 & 7.271 & $<0.001$ \\
\hline \multirow{2}{*}{\multicolumn{2}{|c|}{$\begin{array}{l}\text { Connectivity Index } \\
\text { situation[T.OSFZ] }\end{array}$}} & 35.927 & 41.795 & 0.860 & 0.391 \\
\hline & & 0.044 & 0.320 & 0.138 & 0.891 \\
\hline \multicolumn{2}{|c|}{ Connectivity Index:situation[T.OSFZ] } & 21.457 & 51.937 & 0.413 & 0.680 \\
\hline \multicolumn{2}{|l|}{ Residual standard error: } & \multicolumn{4}{|c|}{0.650 on 141 degrees of freedom } \\
\hline Multiple R-squared: & 0.033 & & \multicolumn{2}{|c|}{ Adjusted R-squared } & 0.0128 \\
\hline F-statistic: & \multicolumn{2}{|c|}{1.623 on 3 and $141 \mathrm{DF}$} & \multicolumn{2}{|c|}{ p-value : } & 0.187 \\
\hline
\end{tabular}


Table 6: ANCOVA table and summary examining the effect of the connectivity index and situation factors on pediveliger abundance ( $\log _{10}$ transform) in collectors. Significant values are in bold $(\mathrm{p}<0.05)$.

\begin{tabular}{|c|c|c|c|c|c|}
\hline Ancova Table & Df & Sum Sq & Mean Sq & F value & $\operatorname{Pr}(>\mathbf{F})$ \\
\hline Connectivity Index & 1 & 3.286 & 3.286 & 5.4130 & $<0.05$ \\
\hline Situation & 1 & 32.510 & 32.510 & 53.554 & $<0.001$ \\
\hline Connectivity Index:Situation & 1 & 5.009 & 5.009 & 8.251 & $<0.005$ \\
\hline Residuals & 110 & 66.775 & 0.607 & & \\
\hline \multicolumn{2}{|l|}{ Ancova Summary } & Estimate & $\begin{array}{c}\text { Std } \\
\text { Error }\end{array}$ & T value & $\operatorname{Pr}(>\mathbf{T})$ \\
\hline \multicolumn{2}{|l|}{ (Intercept) } & 1.294 & 0.3855 & 3.356 & $<0.01$ \\
\hline \multirow{2}{*}{\multicolumn{2}{|c|}{$\begin{array}{c}\text { Connectivity Index } \\
\text { situation[T.OSFZ] }\end{array}$}} & 6.410 & 58.406 & 0.110 & 0.9128 \\
\hline & & -0.042 & 0.441 & -0.095 & 0.9244 \\
\hline \multicolumn{2}{|c|}{$\begin{array}{r}\text { Connectivity } \\
\text { Index:situation[T.OSFZ] }\end{array}$} & 202.592 & 70.530 & 2.872 & $<0.01$ \\
\hline Residual standard error: & \multicolumn{5}{|c|}{0.779 on 110 degrees of freedom } \\
\hline Multiple R-squared: & $\begin{array}{r}0.37 \\
93 \\
\end{array}$ & & \multicolumn{2}{|c|}{ Adjusted R-squared } & 0.362 \\
\hline F-statistic: & 22.4 & and $110 \mathrm{DF}$ & & p-value : & $<0.001$ \\
\hline
\end{tabular}


Table 7: Simultaneous tests for general linear hypotheses with Tukey Contrasts Multiple Comparisons of Means, fitted on an analysis of variance model to examine the effect of sampling sites on large umbo larvae abundance. $p$-values in bold are significant at the $95 \%$ confidence limit.

\begin{tabular}{|c|c|c|c|c|}
\hline Linear Hypotheses: & Estimate & Std Error & T value & $\operatorname{Pr}(>\mathbf{T})$ \\
\hline marseillan_ISFZ - marseillan_OSFZ $==0$ & 0.089 & 0.197 & 0.452 & 0.999 \\
\hline listel_OSFZ - marseillan_OSFZ $==0$ & 0.360 & 0.202 & 1.782 & 0.625 \\
\hline meze_ISFZ - marseillan_OSFZ $=0$ & 0.103 & 0.197 & 0.525 & 0.999 \\
\hline meze_OSFZ - marseillan_OSFZ $==0$ & 0.280 & 0.228 & 1.231 & 0.919 \\
\hline bouzigues_OSFZ - marseillan_OSFZ $==0$ & 0.938 & 0.297 & 3.154 & $\mathbf{p}<0.05$ \\
\hline bouzigues_ISFZ - marseillan_OSFZ $==0$ & 0.378 & 0.197 & 1.915 & 0.535 \\
\hline balaruc_OSFZ - marseillan_OSFZ $==0$ & 0.278 & 0.202 & 1.375 & 0.862 \\
\hline listel_OSFZ - marseillan_ISFZ $==0$ & 0.271 & 0.197 & 1.372 & 0.864 \\
\hline meze_ISFZ - marseillan_ISFZ == 0 & 0.014 & 0.192 & 0.074 & 1.000 \\
\hline meze_OSFZ - marseillan_ISFZ $==0$ & 0.191 & 0.224 & 0.854 & 0.989 \\
\hline bouzigues_OSFZ - marseillan_ISFZ $==0$ & 0.849 & 0.294 & 2.884 & 0.080 \\
\hline bouzigues_ISFZ - marseillan_ISFZ $==0$ & 0.289 & 0.193 & 1.499 & 0.801 \\
\hline balaruc_OSFZ - marseillan_ISFZ $==0$ & 0.189 & 0.197 & 0.955 & 0.978 \\
\hline meze_ISFZ - listel_OSFZ $==0$ & -0.256 & 0.197 & -1.299 & 0.894 \\
\hline meze_OSFZ - listel_OSFZ $==0$ & -0.080 & 0.228 & -0.351 & 1.000 \\
\hline bouzigues_OSFZ - listel_OSFZ $==0$ & 0.578 & 0.297 & 1.943 & 0.515 \\
\hline bouzigues_ISFZ - listel_OSFZ $==0$ & 0.018 & 0.197 & 0.091 & 1.000 \\
\hline balaruc_OSFZ - listel_OSFZ $==0$ & -0.082 & 0.202 & -0.407 & 0.999 \\
\hline meze_OSFZ - meze_ISFZ $==0$ & 0.176 & 0.223 & 0.790 & 0.993 \\
\hline bouzigues_OSFZ - meze_ISFZ $==0$ & 0.834 & 0.294 & 2.836 & 0.091 \\
\hline bouzigues_ISFZ - meze_ISFZ $==0$ & 0.274 & 0.193 & 1.424 & 0.839 \\
\hline balaruc_OSFZ - meze_ISFZ $==0$ & 0.174 & 0.197 & 0.883 & 0.986 \\
\hline bouzigues_OSFZ - meze_OSFZ $==0$ & 0.658 & 0.315 & 2.086 & 0.420 \\
\hline bouzigues_ISFZ - meze_OSFZ $==0$ & 0.098 & 0.223 & 0.438 & 0.999 \\
\hline balaruc_OSFZ - meze_OSFZ $==0$ & -0.002 & 0.228 & -0.010 & 1.000 \\
\hline bouzigues_ISFZ - bouzigues_OSFZ $==0$ & -0.560 & 0.294 & -1.903 & 0.542 \\
\hline balaruc_OSFZ - bouzigues_OSFZ $=0$ & -0.660 & 0.297 & -2.220 & 0.339 \\
\hline balaruc_OSFZ - bouzigues_ISFZ $==0$ & -0.100 & 0.197 & -0.507 & 0.999 \\
\hline
\end{tabular}


Table 8: Simultaneous tests for general linear hypotheses with Tukey Contrasts Multiple Comparisons of Means, fitted on an analysis of variance model to examine the effect of sampling sites on pediveliger abundance. $p$-values in bold are significant at the $95 \%$ confidence level.

\begin{tabular}{|c|c|c|c|c|}
\hline Linear Hypotheses: & Estimate & Std Error & T value & $\operatorname{Pr}(>T)$ \\
\hline marseillan_ISFZ - marseillan_OSFZ $==0$ & -0.208 & 0.265 & -0.782 & 0.993 \\
\hline listel_OSFZ - marseillan_OSFZ $==0$ & 1.367 & 0.261 & 5.225 & $<0.01$ \\
\hline meze_ISFZ - marseillan_OSFZ $==0$ & -0.085 & 0.261 & -0.326 & 1.000 \\
\hline meze_OSFZ - marseillan_OSFZ $==0$ & 0.877 & 0.286 & 3.057 & 0.053 \\
\hline bouzigues_OSFZ - marseillan_OSFZ $==0$ & 1.919 & 0.359 & 5.337 & $<0.01$ \\
\hline bouzigues_ISFZ - marseillan_OSFZ $==0$ & 0.002 & 0.280 & 0.007 & 1.000 \\
\hline balaruc_OSFZ - marseillan_OSFZ $==0$ & 0.651 & 0.261 & 2.492 & 0.206 \\
\hline listel_OSFZ - marseillan_ISFZ $==0$ & 1.574 & 0.261 & 6.019 & $<0.01$ \\
\hline meze_ISFZ - marseillan_ISFZ $==0$ & 0.122 & 0.261 & 0.468 & 0.999 \\
\hline meze_OSFZ - marseillan_ISFZ $==0$ & 1.084 & 0.286 & 3.781 & $<0.01$ \\
\hline bouzigues_OSFZ - marseillan_ISFZ $==0$ & 2.126 & 0.359 & 5.914 & $<0.01$ \\
\hline bouzigues_ISFZ - marseillan_ISFZ $==0$ & 0.209 & 0.280 & 0.748 & 0.995 \\
\hline balaruc_OSFZ - marseillan_ISFZ $=0$ & 0.859 & 0.261 & 3.285 & $<0.05$ \\
\hline meze_ISFZ - listel_OSFZ $==0$ & -1.452 & 0.257 & -5.637 & $<0.01$ \\
\hline meze_OSFZ - listel_OSFZ $==0$ & -0.490 & 0.283 & -1.73 & 0.661 \\
\hline bouzigues_OSFZ - listel_OSFZ $==0$ & 0.551 & 0.356 & 1.547 & 0.775 \\
\hline bouzigues_ISFZ - listel_OSFZ $==0$ & -1.365 & 0.276 & -4.933 & $<0.01$ \\
\hline balaruc_OSFZ - listel_OSFZ $==0$ & -0.715 & 0.257 & -2.776 & 0.110 \\
\hline meze_OSFZ - meze_ISFZ $==0$ & 0.962 & 0.283 & 3.397 & 0.020 \\
\hline bouzigues_OSFZ - meze_ISFZ $=0$ & 2.004 & 0.356 & 5.619 & $<0.01$ \\
\hline bouzigues_ISFZ - meze_ISFZ $==0$ & 0.087 & 0.276 & 0.316 & 1.000 \\
\hline balaruc_OSFZ - meze_ISFZ $==0$ & 0.737 & 0.257 & 2.861 & 0.089 \\
\hline bouzigues_OSFZ - meze_OSFZ $==0$ & 1.042 & 0.375 & 2.775 & 0.109 \\
\hline bouzigues_ISFZ - meze_OSFZ $==0$ & 0.874 & 0.300 & -2.909 & 0.079 \\
\hline balaruc_OSFZ - meze_OSFZ $=0$ & -0.224 & 0.283 & -0.794 & 0.992 \\
\hline bouzigues_ISFZ - bouzigues_OSFZ $==0$ & -1.917 & 0.370 & -5.171 & $<0.01$ \\
\hline balaruc_OSFZ - bouzigues_OSFZ $=0$ & -1.267 & 0.356 & -3.553 & $<0.05$ \\
\hline balaruc_OSFZ - bouzigues_ISFZ $==0$ & 0.649 & 0.276 & 2.348 & 0.272 \\
\hline
\end{tabular}


Table 9: Analysis of the linear multiple regression between the pediveliger abundance and environmental variables. Significant values $(\mathrm{p}<0.05)$ are in bold.

\begin{tabular}{|c|c|c|c|c|}
\hline \multicolumn{5}{|c|}{ 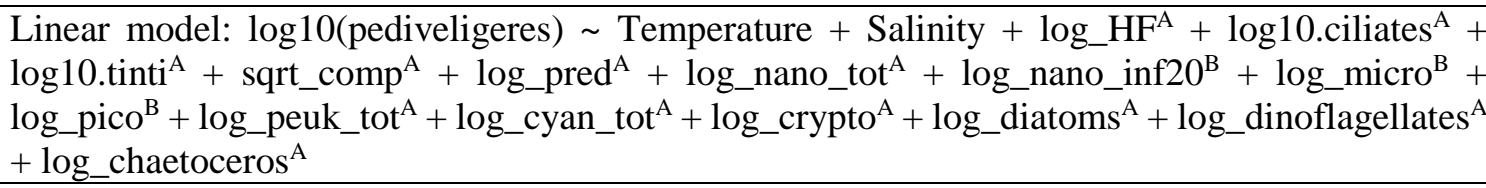 } \\
\hline Coefficients & Estimate & Std. Error & $\mathrm{T}$ & $p$ \\
\hline Intercept & -6.927 & 4.881 & -1.419 & 0.162 \\
\hline Temperature & -0.0278 & 0.071 & -0.392 & 0.696 \\
\hline Salinity & 0.142 & 0.109 & 1.296 & 0.201 \\
\hline $\log \_\mathbf{H F} \mathbf{F}^{A}$ & 0.922 & 0.416 & 2.215 & 0.031 \\
\hline $\log _{-}$ciliates $^{\mathrm{A}}$ & 0.654 & 0.535 & 1.223 & 0.227 \\
\hline $\log _{-}$tinti $^{\mathrm{A}}$ & -0.746 & 0.263 & -2.835 & 0.006 \\
\hline sqrt_comp ${ }^{\mathrm{A}}$ & 0.069 & 0.086 & 0.801 & 0.427 \\
\hline log_pred ${ }^{\mathrm{A}}$ & 0.075 & 2.035 & 0.037 & 0.970 \\
\hline log_nano_tot ${ }^{\mathrm{A}}$ & 1.859 & 0.728 & 2.551 & 0.014 \\
\hline log_nano_inf $20^{B}$ & -2.349 & 2.569 & -0.914 & 0.365 \\
\hline log_micro ${ }^{\mathrm{B}}$ & -0.5432 & 1.741 & -0.312 & 0.756 \\
\hline log_pico ${ }^{\mathrm{B}}$ & -3.292 & 5.532 & -0.595 & 0.554 \\
\hline log_peuk_tot ${ }^{\mathrm{A}}$ & -1.219 & 0.604 & -2.018 & 0.049 \\
\hline log_cyan_tot ${ }^{\mathrm{A}}$ & 0.821 & 0.340 & 2.415 & 0.019 \\
\hline $\log$ crypto $^{\mathrm{A}}$ & -2.282 & 2.163 & -1.055 & 0.2972 \\
\hline $\log$ diatoms ${ }^{A}$ & 0.530 & 0.247 & 2.146 & 0.037 \\
\hline log_dinoflagellates ${ }^{\mathrm{A}}$ & -0.949 & 0.499 & -1.901 & 0.063 \\
\hline $\log \_$chaetoceros ${ }^{\mathrm{A}}$ & -0.094 & 0.137 & -0.686 & 0.4963 \\
\hline Residual standard error: & \multicolumn{4}{|c|}{0.7743 on 45 degrees of freedom } \\
\hline Multiple $\mathrm{R}^{2}$ & \multicolumn{4}{|c|}{0.691} \\
\hline Adjusted $\mathrm{R}^{2}$ & \multicolumn{4}{|l|}{$\mathbf{0 . 5 7 5}$} \\
\hline$F(\mathrm{df}=17,45)$ & \multicolumn{4}{|l|}{5.939} \\
\hline $\mathbf{p}$ & \multicolumn{4}{|l|}{$<0.0001$} \\
\hline
\end{tabular}


Figure 1: (A) The Mediterranean Thau lagoon in the South of France and (B) sampling sites in the Thau lagoon. ISFZ: Inside the ShellFish Farming Zone (monitoring took place under farm structures); OSFZ: Outside the Shellfish Farming Zone (monitoring took place at specially designed mooring systems, see Lagarde et al 2017). Colored symbols locate the 8 sampling sites with 3 ISFZ sites: Marseillan_ISFZ (green plus), Meze_ISFZ (red triangle point up) and Bouzigues_ISFZ (black open circle) and 5 OSFZ sites: Marseillan_OSFZ (yellow square cross), Listel_OSFZ (magenta triangle point down), Meze_OSFZ (cyan diamond), Bouzigues_OSFZ (grey circle cross) and Balaruc_OSFZ (blue cross) where pelagic larvae and benthic Pacific oyster larvae, spat abundances, hydrological and plankton data were monitored. Grey boxes: shellfish farms, dark grey areas: towns

Figure 2: Diagram showing the schedule for setting up the collectors from June to October. Red $\mathrm{X}$ marks the date the coupelles were harvested to count the pediveliger and post-larvae, the blue $\mathrm{X}$ marks the date the coupelles were harvested to count the oyster spat. Figure adapted from Lagarde et al. 2019.

Figure 3: a) Sampling site to collect spat outside the shellfish farming zone with 3 control moorings and 3 replicated spat collection mooring systems. b) Each mooring system supported a set of 2 coupelles collectors. The first collector was immersed for 2 weeks and the second for 4 weeks before being replaced by a new collector for the next series. Figure adapted from Lagarde et al. 2019 and Lagarde et al. 2017.

Figure 4: Mooring system inside the shellfish farming zone. PP: polypropylene. The breeding structure carried a first series of 3 replicate collectors for 2 weeks of submersion to assess 
pediveliger abundance and a second series of 4 weeks of submersion to assess oyster spat. The control set of 3 collectors is not shown.

Figure 5: a) Sampling strategy at 3 levels (high, medium and low) of coupelles collectors b) top view of coupelle collector with 3 replicated counting subunits in yellow. Figure adapted from Lagarde et al. (2017)

Figure 6: Mean $( \pm 95 \% \mathrm{CI})$ oyster spat abundance per plate observed at 8 sampling sites in Thau lagoon, 3 located inside the shellfish farming zone (ISFZ) (Marseillan_ISFZ -green-, Meze_ISFZ -red- and Bouzigues_ISFZ -black-) and five outside (OSFZ) (Marseillan_OSFZ yellow-, Listel_OSFZ -magenta-, Meze_OSFZ -cyan-, Bouzigues_OSFZ -grey- and Balaruc_OSFZ -blue-). Observations were made at 2-week intervals throughout the summer in 2012, 2013, and 2014. Spat abundances were estimated after the collector had been immersed for 4 weeks ( $n=54$ per date and sampling site).

Figure 7: Distributions of oyster D-larvae $\left(\mathrm{n}_{\text {ISFZ }}=46 ; \mathrm{n}_{\mathrm{OSFZ}}=68\right)$, large umbo larvae $\left(\mathrm{n}_{\text {ISFZ }}=\right.$ 66 ; nosfZ $=79)$, pediveliger larvae $\left(n_{I S F Z}=46 ;\right.$ nosfZ $\left.=68\right)$ and oyster spat $\left(n_{\text {ISFZ }}=72 ;\right.$ nosfZ =96) inside (ISFZ) and outside (OSFZ) the shellfish farming zones of Thau lagoon. Mid-line: median; box: $25^{\text {th }}$ and $75^{\text {th }}$ percentiles; whiskers: $1.5 \times$ the interquartile range; circles: outliers. Red crosses: means.

Figure 8: Spatial distribution of the connectivity index $\left(\mathrm{d}^{-1}\right)$ across Thau lagoon averaged based on the 50 simulations run from June $1^{\text {st }}$ to September $29^{\text {th }}$. Colored symbols mark the 8 sampling sites including three ISFZ sites: Marseillan_ISFZ (green plus), Meze_ISFZ (red 
triangle point up) and Bouzigues_ISFZ (black open circle) and five OSFZ sites:

Marseillan_OSFZ (yellow square cross), Listel_OSFZ (magenta triangle point down),

Meze_OSFZ (cyan diamond), Bouzigues_OSFZ (grey circle cross) and Balaruc_OSFZ (blue cross) where pelagic larvae and benthic Pacific oyster larvae, spat abundances, hydrological and plankton data were monitored. Grey boxes indicate the location of shellfish farms.

Figure 9: Boxplot of simulated connectivity at the experimental sampling sites on each collector sampling date $(n=132)$. Different letters indicate significant differences between groups resulting from a Tukey Contrasts Multiple Comparisons test ( $\mathrm{p} \leq 0.05)$. Mid-line: median; box: $25^{\text {th }}$ and $75^{\text {th }}$ percentiles; whiskers: $1.5 \times$ the interquartile range; circle: outliers.

Figure 10: Relationship between connectivity (mean \pm SE) and abundance of a) large umbo larvae $\left(\log _{10} \mathrm{~m}^{-3}, \mathrm{n}_{\mathrm{ISFZ}}=66, \mathrm{n}_{\mathrm{OSFZ}}=79\right)$, b) pediveligers $\left(\log _{10}\right.$ plate $\left.^{-1}, \mathrm{n}_{\mathrm{ISFZ}}=46, \mathrm{n}_{\mathrm{OSFZ}}=68\right)$ at the 8 sampling sites. Colored symbols mark the 8 sampling sites including three ISFZ sites:

Marseillan_ISFZ (green plus), Meze_ISFZ (red triangle point up) and Bouzigues_ISFZ (black open circle) and five OSFZ sites: Marseillan_OSFZ (yellow square cross), Listel_OSFZ (magenta triangle point down), Meze_OSFZ (cyan diamond), Bouzigues_OSFZ (grey circle cross) and Balaruc_OSFZ (blue cross). Black line: OSFZ linear regression line; Red dashed line: ISFZ linear regression line. Letters differentiate the level of the group according to the Tukey Contrasts Multiple Comparisons of Means. Regression lines: Red for Inside Shellfish Farming Zone, Black for Outside Shellfish Farming Zone.

Figure 11: Significant relationship $(\mathrm{p}<0.05)$ between pediveliger abundances and abundances of a) picocyanophyceae, b) diatoms, c) heterotrophic flagellates, d) Total nanophytoplankton, 
e) total picoeukaryotes and f) tintinnids. Symbols indicate values on plots. All data are $\log 10(\mathrm{x}+1)$ transformed, see Table 1 for units.

Figure 12: Plankton abundances that revealed a significant difference $(\mathrm{p}<0.05)$ among sampling sites Marseillan_ISFZ ( $\left.\mathrm{n}_{\text {Marseillan_ISFZ }}=25\right)$, Bouzigues_ISFZ $\left(\mathrm{n}_{\text {Bouzigues_ISFZ }}=25\right)$ and Listel_OSFZ $\left(\mathrm{n}_{\text {Listel_oSFZ }}=17\right)$. Red Xs indicate means. Nanophytoplankton and picoeukaryotes abundances in $10^{6}$ cell $1^{-1}$, Chaetoceros spp in cell $1^{-1}$, competitors in $10^{3}$ individuals per cubic meter and predators in $\log _{10}$ individuals per cubic meter. 


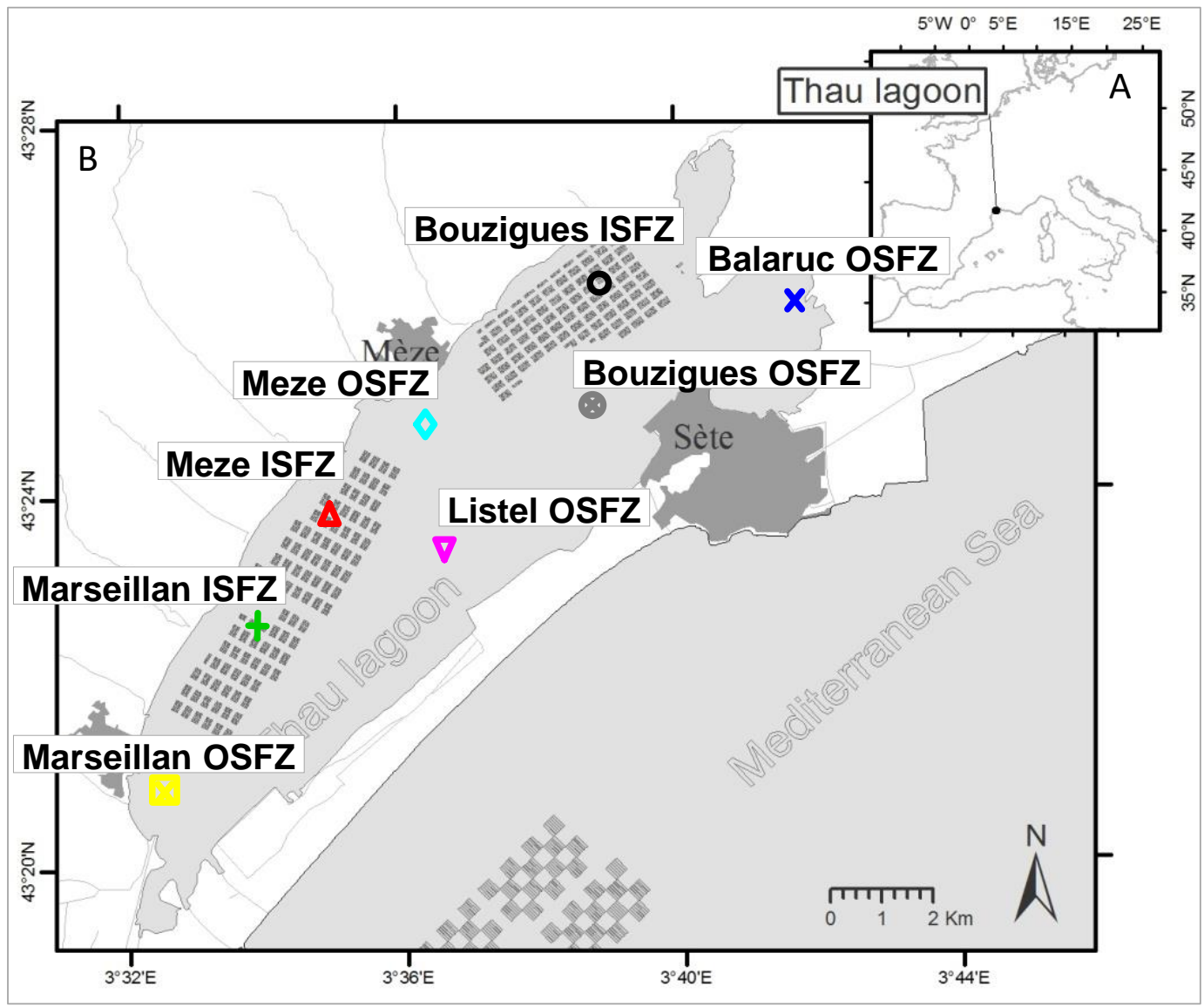

Figure 1 


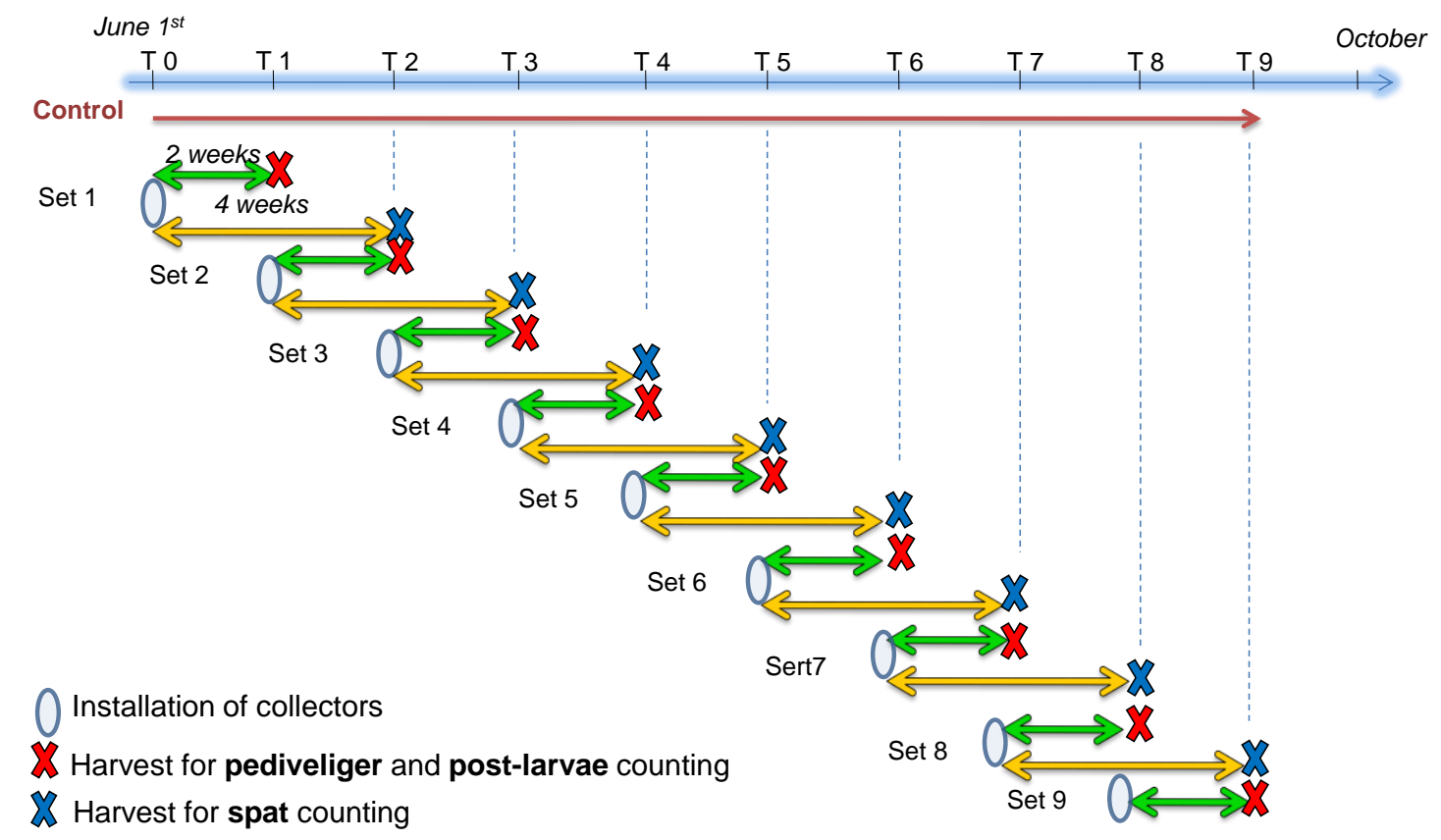

Figure 2 

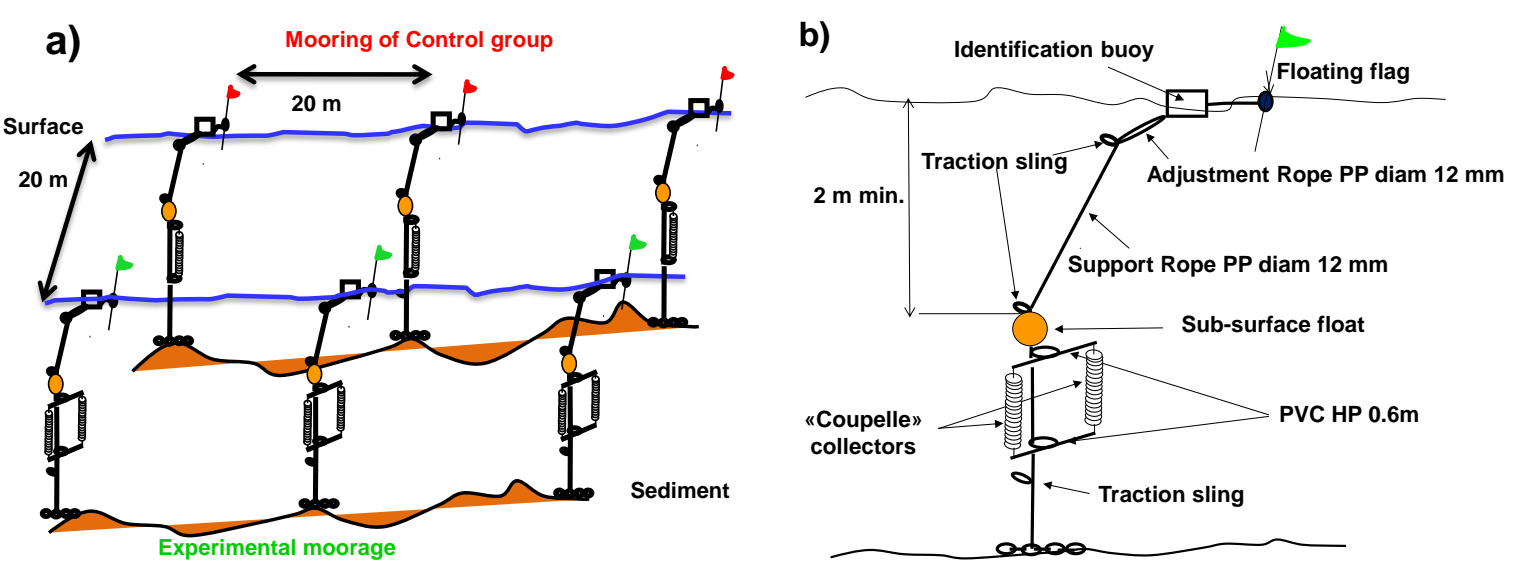

Figure 3 


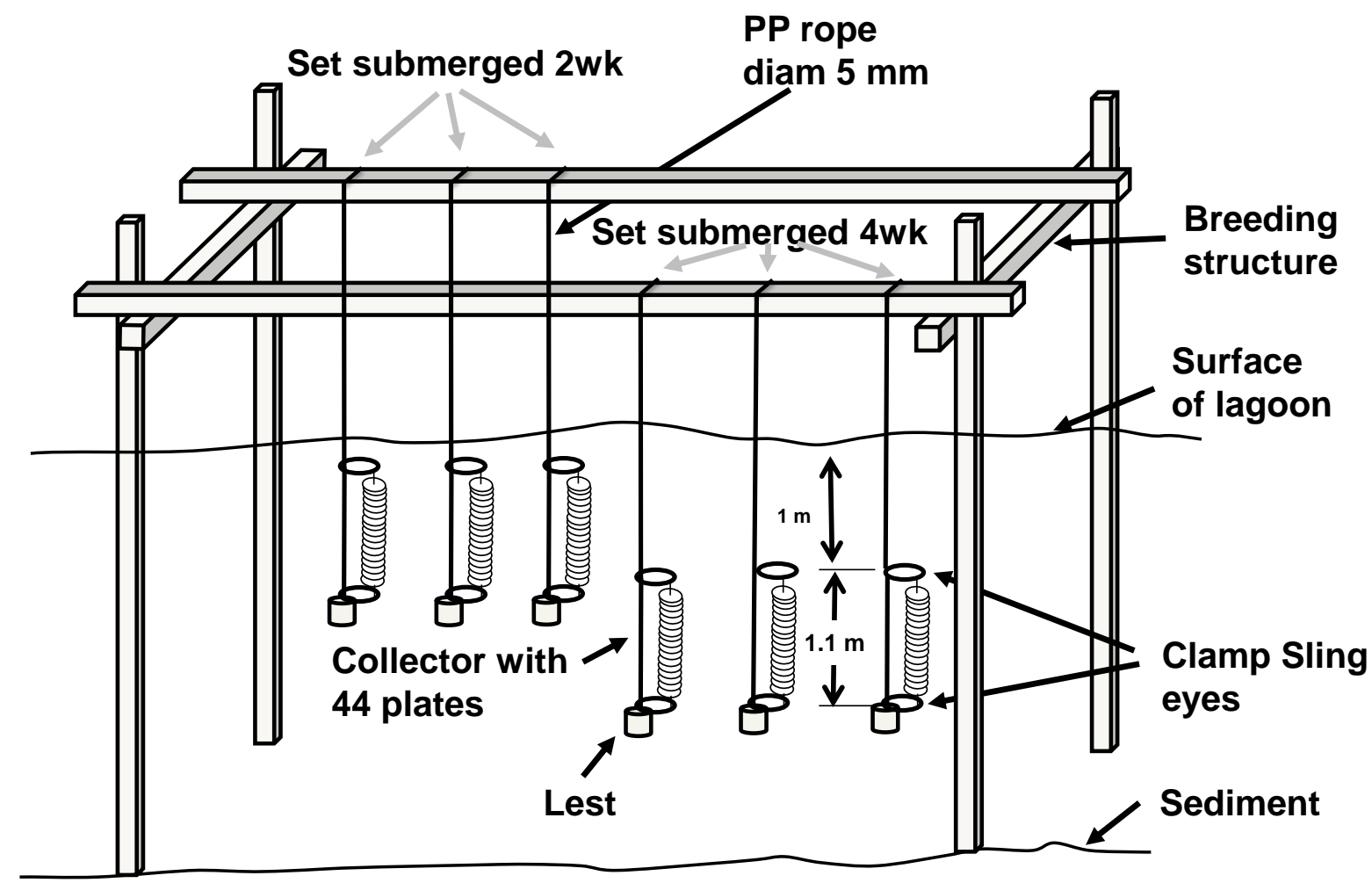

Figure 4 
a)

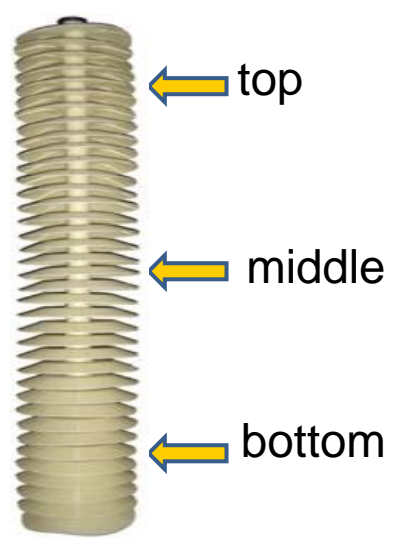

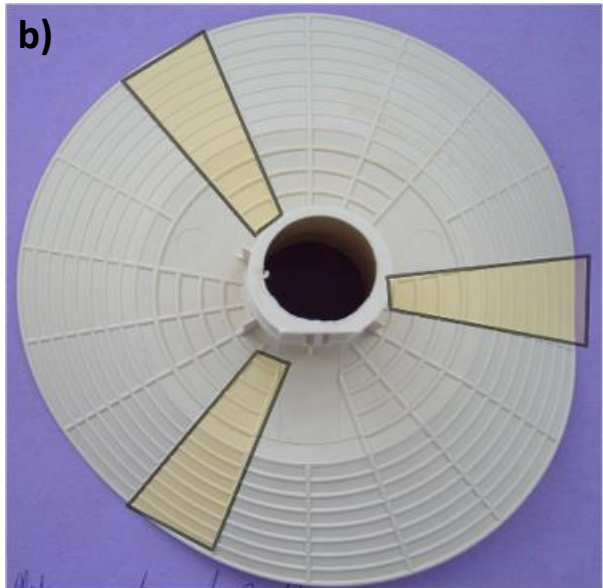

Figure 5 


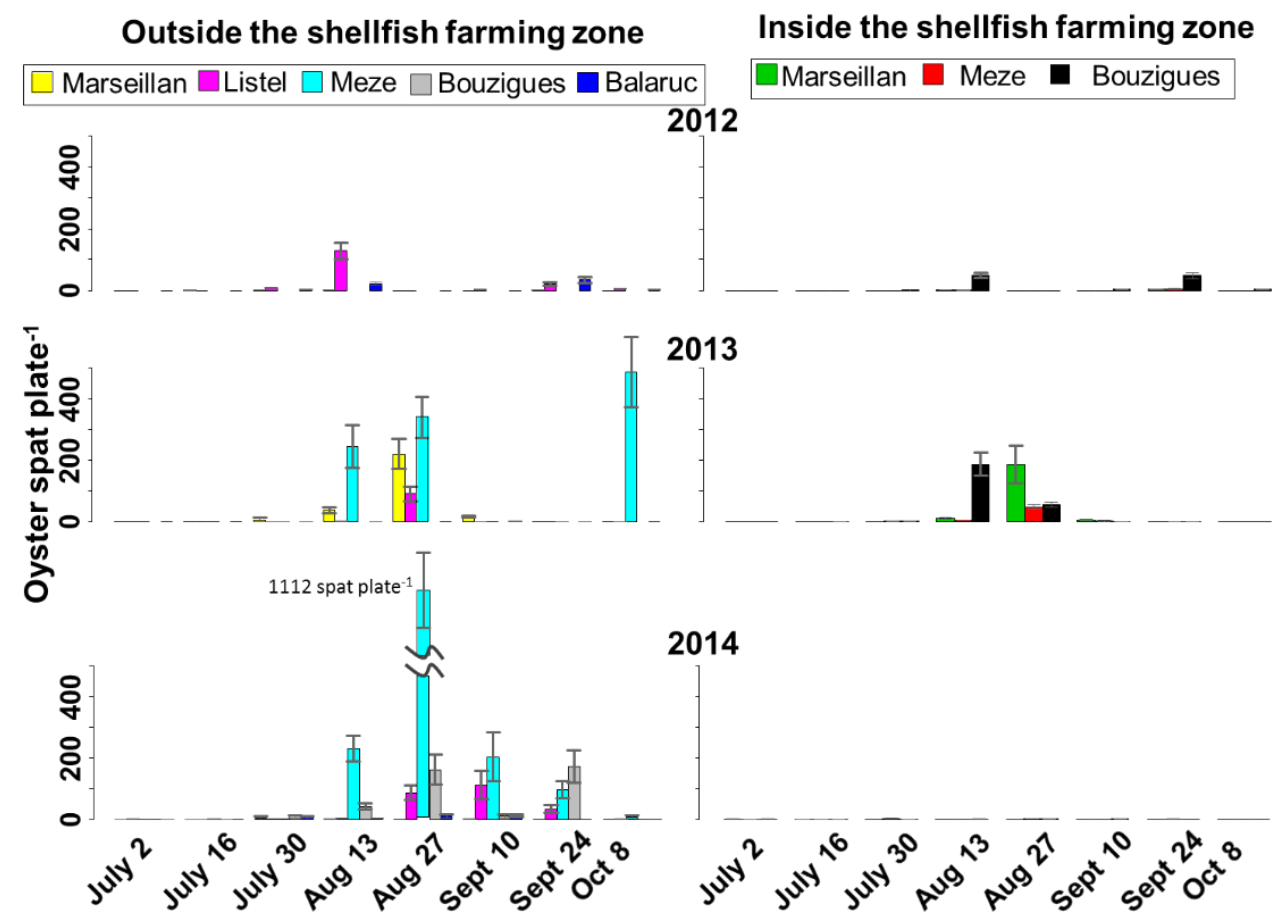

Figure 6

50 


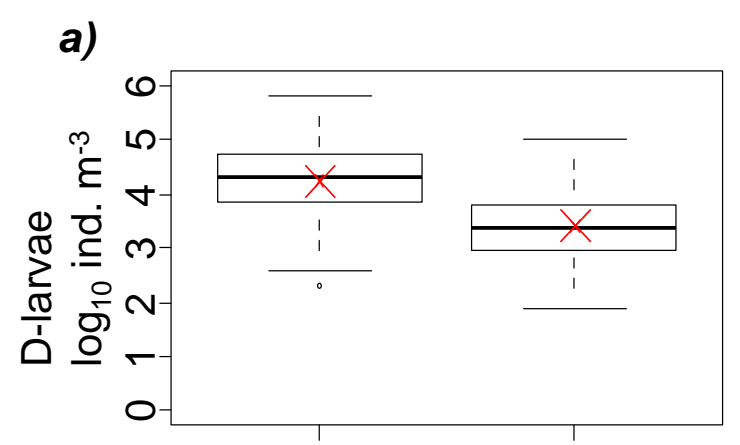

b)
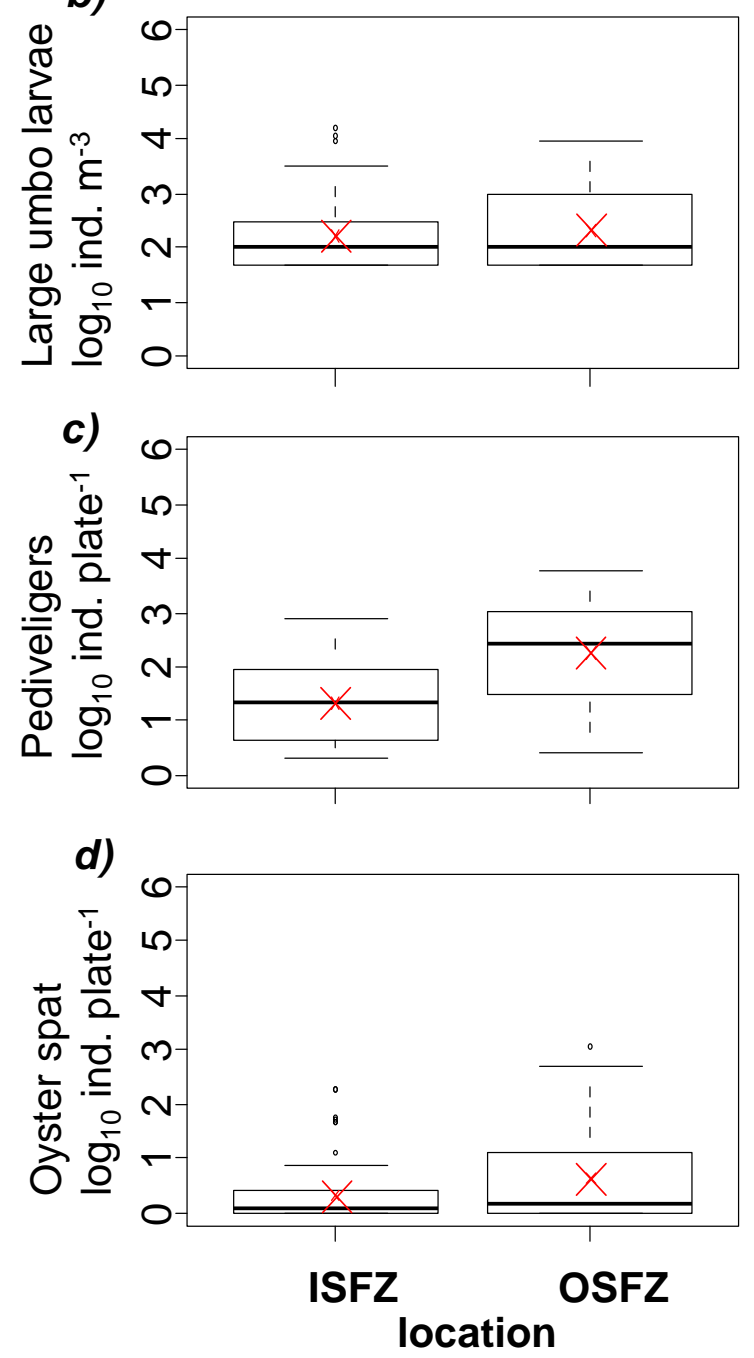

Figure 7 

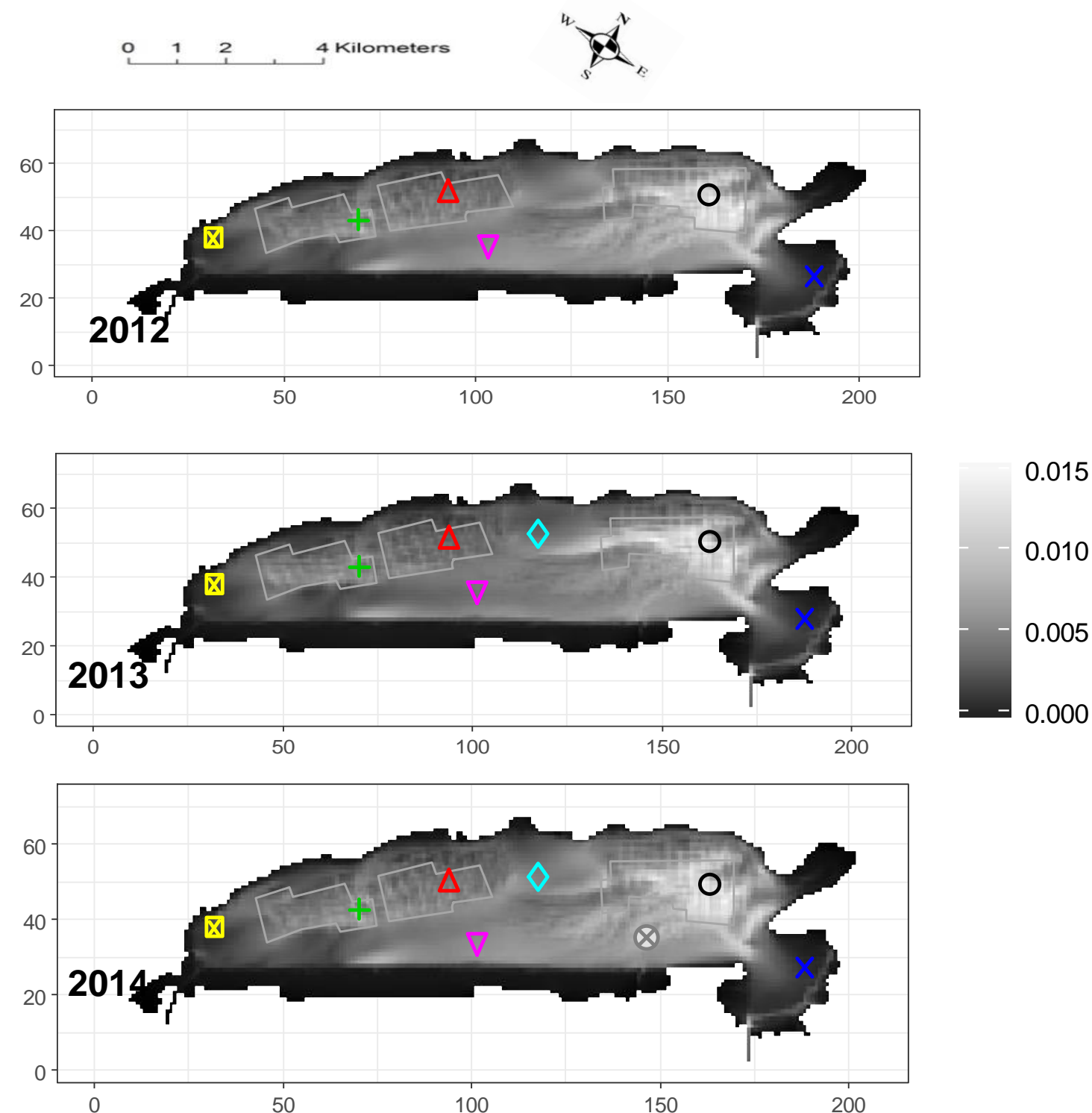

Figure 8 


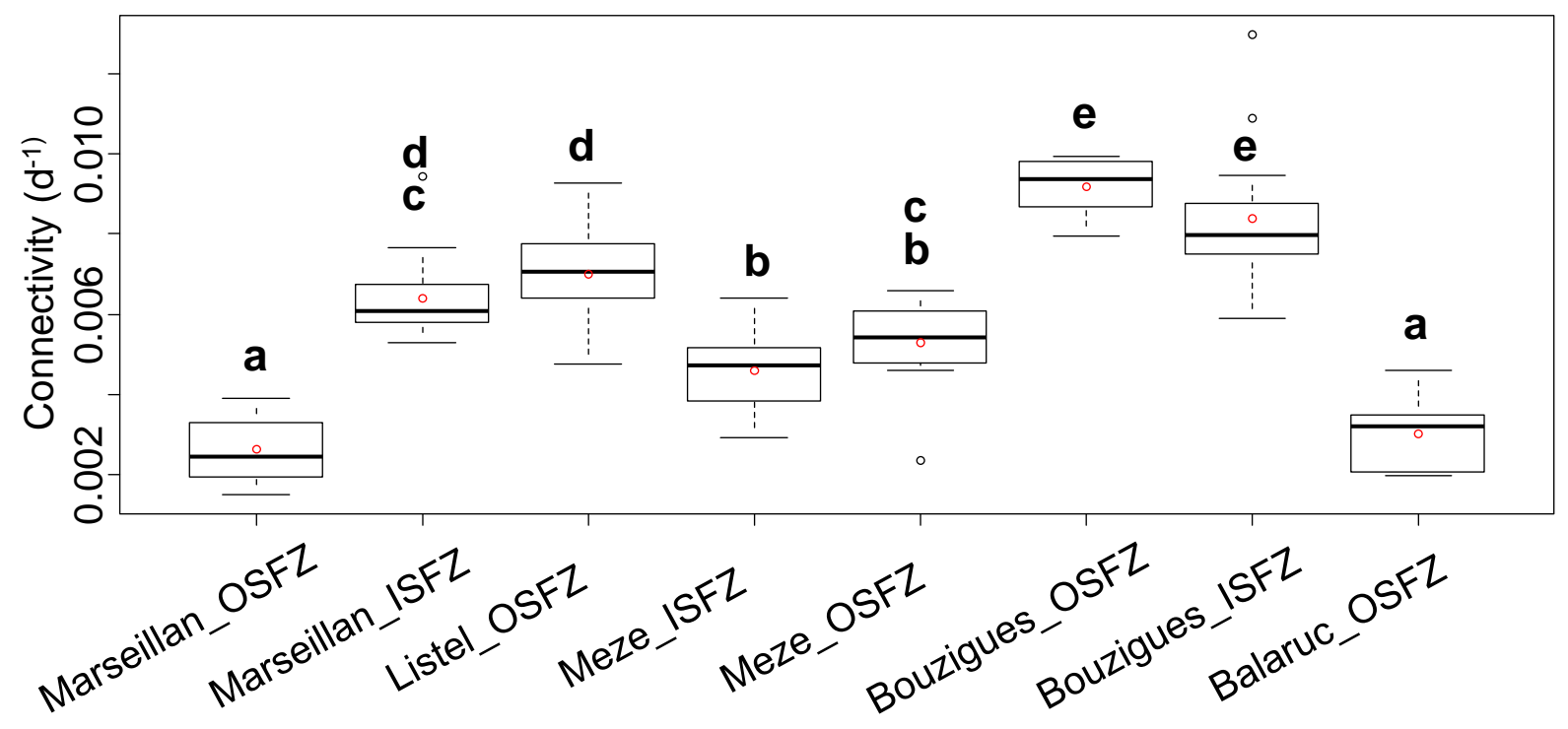

Sampling sites

Figure 9 
Inside the shellfish farming zone

+ Marseillan_ISFZ $\triangle$ Meze_ISFZ O Bouzigues_ISFZ

Outside the shellfish farming zone

$凶$ Marseillan OSFZ $\nabla$ Listel OSFZ $\diamond$ Meze OSFZ $\otimes$ Bouzigues OSFZ X Balaruc OSFZ
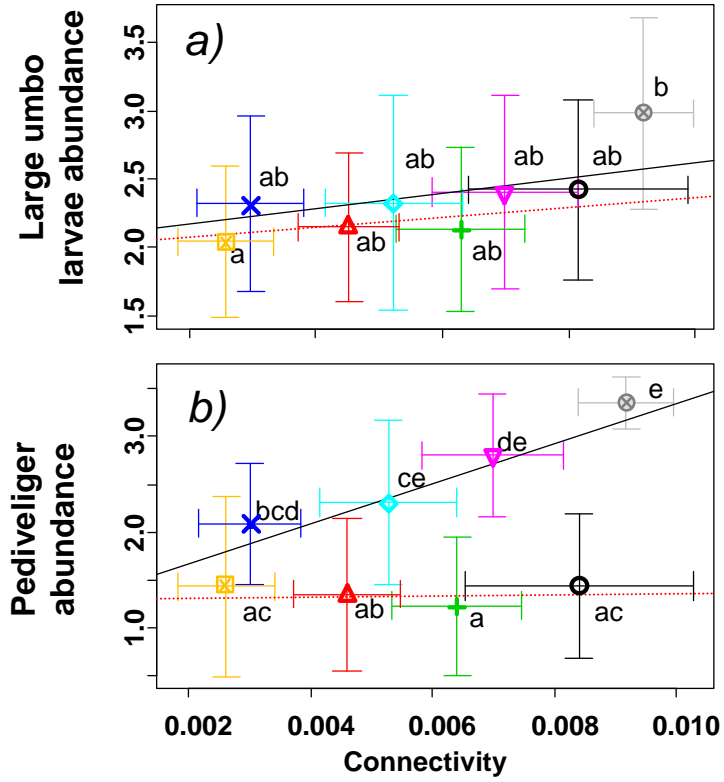

Figure 10 


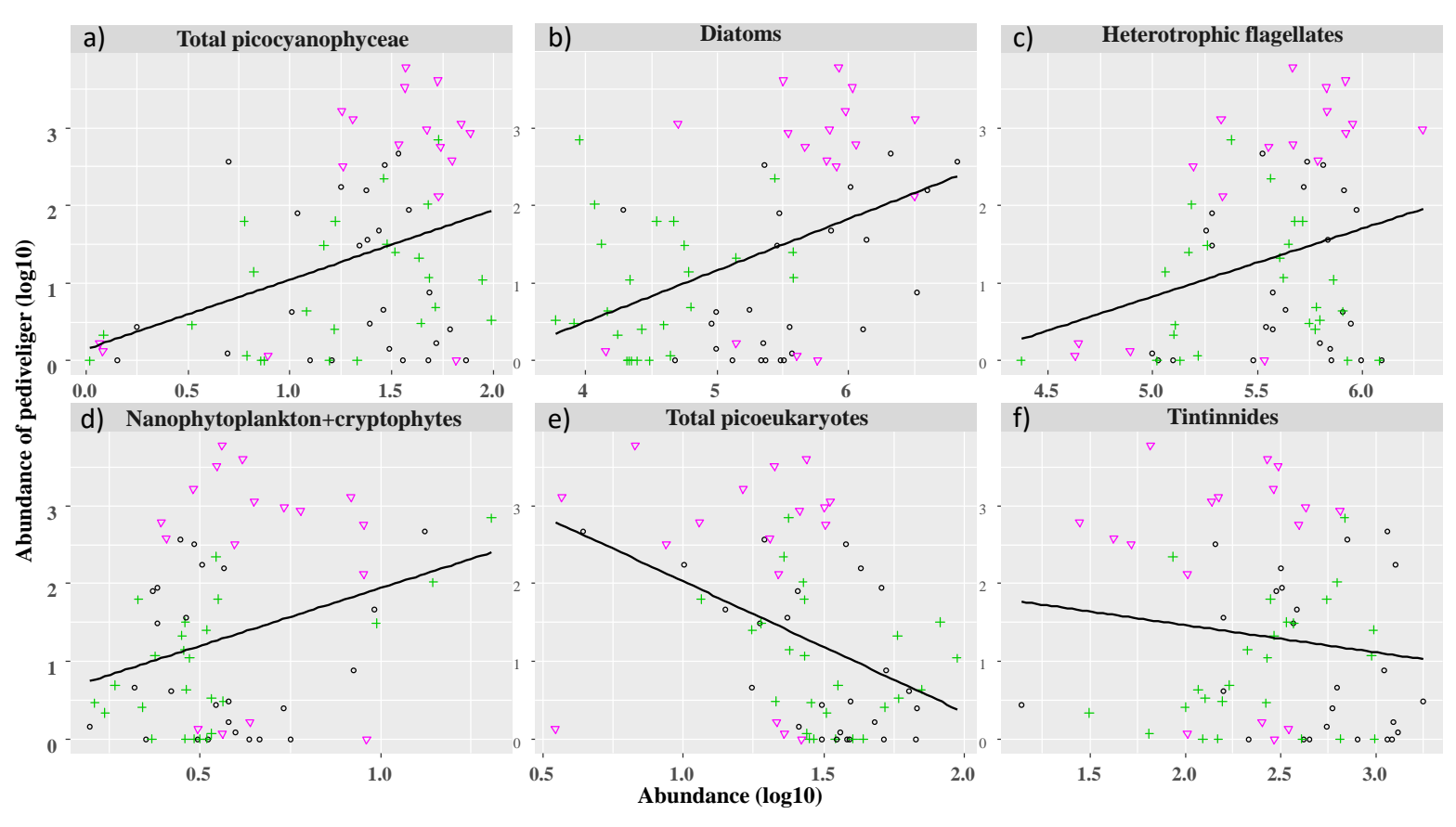

\section{Station}

\section{Marseillan \\ Bouzigues \\ $\nabla$ Listel_OSFZ}

Figure 11 

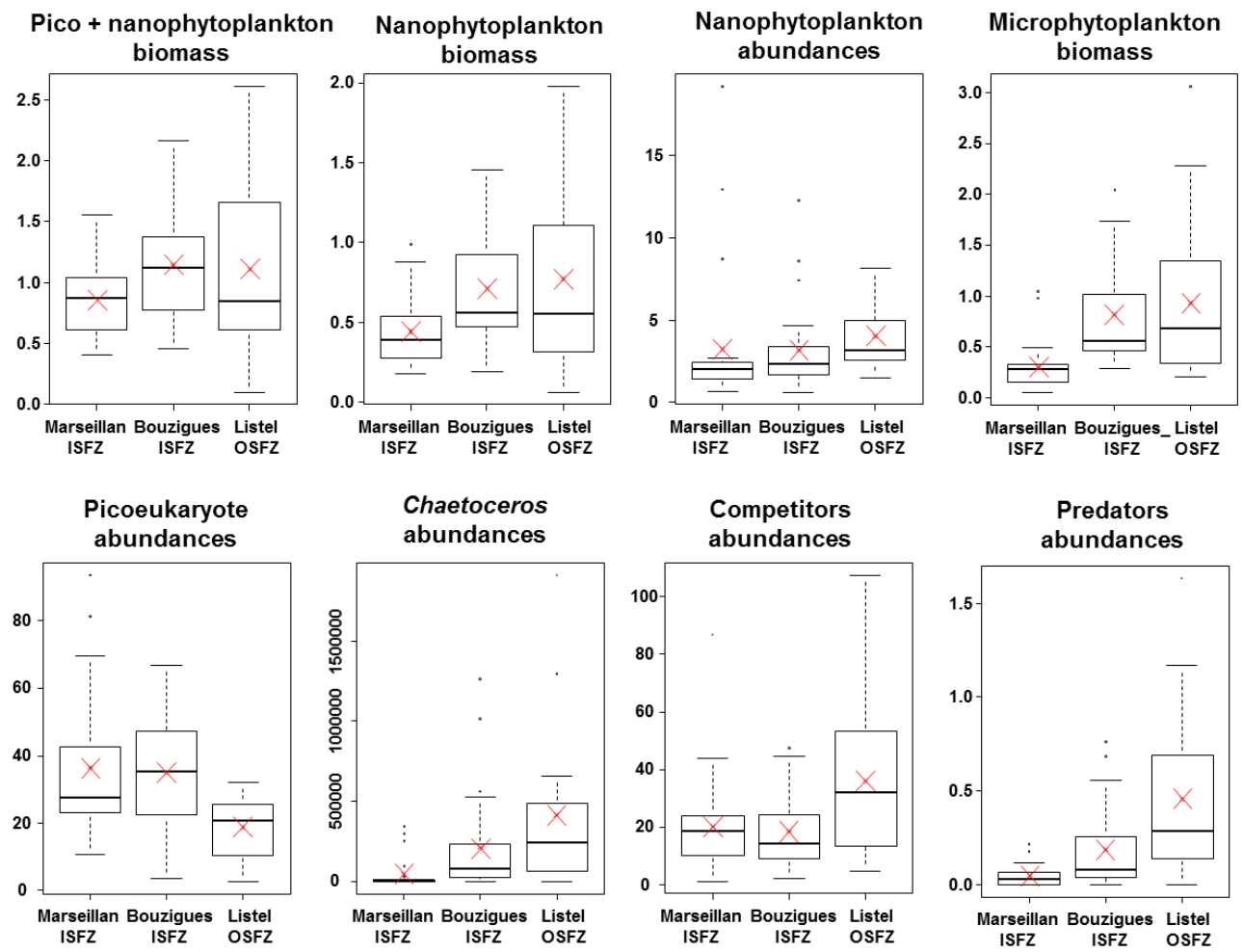

Figure 12 